\title{
1. Composing Communities
}

\author{
Languages of Madness in Remission Letters
}

\begin{abstract}
An examination of the intellectual context within which the royal notaries worked sheds light on the complex layers of language about madness in the fourteenth and fifteenth centuries. Legal texts conceived of mental illness as an inability to comprehend, and therefore a propensity to infringe upon, the rules governing social and legal interactions. The royal notaries were not solely influenced by legal terminology and concepts, however. The language they used to describe madness pulled from a wide variety of discourses to present a fuller understanding of the meaning of mental incapacity. Unlike scholars writing within a single discourse, however, notaries often combined terms in an effort to express their particular image of madness.
\end{abstract}

Keyterms: Remission, Notaries, Translation, Language

When Jehannecte Troppé murdered her husband, Thomas Baillet, her 'relatives and immediate family'1 sought a letter of remission for her. Jehannecte herself was unable to join them since she was in prison in the town of Bayeux at the time. Two months after the murder the family traveled about 153 miles (247 kilometers) from Bayeux to Paris, ${ }^{2}$ where the duke of Bedford was holding the position of Regent for the two-year-old English king of France, Henry. There, Jehannecte's family, which probably included her father Thomas, mentioned by name in the letter, met with the royal notary, Jean de Rinel. With his help, the family composed a letter explaining Jehannecte's crime and asking that she be pardoned. ${ }^{3}$ It is impossible to know whether the Troppé family arrived

1 AN JJ 173 no 63 fo 33v. Edited in Le Cacheux 1907-1908, pp. 181-183: 'parens et amis'. See Gauvard 1991, pp. 643-651 for a discussion of the meaning of 'parens et amis charnels'.

2 The trip would have taken around three days on a horse or nine or more days on foot. For an estimate of travel time I used Dunn and Davidson 2000, p. 487

3 For more on these documents, see Davis 1987, pp. 7-25; Gauvard 1991, vol. 1, pp. 59-110.

Pfau, A., Medieval Communities and the Mad: Narratives of Crime and Mental Illness in Late Medieval France. Amsterdam: Amsterdam University Press 2021 DOI: 10.5117/9789462983359_CHO1 
in Paris intending to mention that Jehannecte was mad or whether they came to that decision through consultation with the notary Jean de Rinel, but it is clear that the letter was composed with madness as the central theme.

According to the letter, one night about fifteen days before the feast of All Saints in 1424, Jehannecte got up out of bed and began destroying her clothes, their pots and pans, and all the other household items that she could find. The next day, she opened a bag of bread flour and scattered it around the house, refusing to tell her husband why. Thomas Baillet hoped his wife would stop this behavior and they could live 'peaceably together, as they had been always since their marriage'. ${ }^{4}$ On the night of 4 November, Jehannecte, her husband, and her eleven-year-old brother were lying in bed together when she picked up a rock and hit her husband on the head several times, then got back into bed beside him. When Thomas Baillet was able to speak, he told her to light the candle. Jehannecte had to go to a neighbor's house in order to find fire, even though they had covered their own when they went to bed. When she saw her husband's wounds, Jehannecte was shocked and had no idea that she had caused them. However, when Thomas Baillet died eight days later, she was arrested and put in prison in Bayeux, where, as her family claimed, she and the child with which she was pregnant were in danger of dying. These were the basic points of the story that the family told, but the way that they told it framed the narrative in terms of madness. Having made the choice to describe Jehannecte's crime in this way, the supplicants and the notary had to find or create an acceptable shared language and understanding of madness with which to do so. 5 Whereas Jean de Rinel was literate, Latinate, and licensed in the law, the letter was composed in French and would be read aloud to the community where Jehannecte Troppé was in prison.

\section{Letters of Remission}

The first letters of remission appeared in the records of the French king's chancery at the beginning of the fourteenth century. ${ }^{6}$ The earliest of these letters were mostly granted to people who claimed to have been falsely

4 AN JJ 173 no 63 fo 33v. Edited in Le Cacheux 1907-1908, pp. 181-183: 'se tenissent paisiblement ensemble, come ilz avoient esté tousjours depuis leur mariage'.

5 In this study of the vernacular French vocabularies of madness, I am inspired in part by Helmut Puff's proviso that what is significant 'is not language in its abstraction', but instead 'the ways in which historical actors, magistrates, officials, translators, redactors, experts, or defendants used language'. Puff 2003, p. 3 .

6 The first remission letter appeared in May of 1304. See Gauvard 1991, vol. 1, 64. 
accused or to forgive members of the nobility who had been engaged in warfare that was not sanctioned by the king. ${ }^{7}$ Over time, letters were also granted to non-nobles as a pardon for crimes they had committed. Through this development, the French king made a number of interrelated claims about his power and authority. ${ }^{8}$ With these letters, the king was exercising his powers of grace and mercy by choosing to grant life instead of death to his erring subjects. His mercy did not reflect justice, but, like God's mercy established in the promise of the New Testament, it acted above human perceptions of punishment as a direct correlation to crime. ${ }^{9}$ Indeed, this understanding of remission is written into the framing text that surrounded the individual stories about crimes. The letter was written in the king's voice, and the act of remission was a recorded speech act, where the king said, 'We, preferring mercy to the rigor of justice [...], grant remission'. ${ }^{10}$ On a lower plane, remission letters demonstrated the king's power to override the execution of justice in his realm, thus making him the equal of the Emperor. ${ }^{11}$ As these related concepts of mercy and authority demonstrate, remission was not about justice but about power. The king could and did act above the law in granting pardons, and there was no need for petitioners to establish their innocence. Most of the petitioners admitted their guilt, much as they might in a confession to a man of God, but they were careful to establish that the crime was unusual, and not part of a criminal lifestyle. The king was gracious in his mercy, granting remission for treason, and even in some cases pardoning an individual for a crime for which his or her partner had already been executed. ${ }^{2}$

7 Some of these early letters can be found edited at numbers $3759,3914,3986,4054,4177,4231$, $4322,4357,4603,4767,4788,4841$, and 5101 in Jassemin and Vallée 1999, vol. 2. See also Justine Firnhaber-Baker's work on the subject of private warfare through the examination of remission letters. Firnhaber-Baker 2014; Firnhaber-Baker 2007; Firnhaber-Baker 2006.

8 It has been argued that the fourteenth century saw an increased effort on the part of the king to demonstrate his power through the legal system. Brissaud 1971, pp. 552-556; Cohen 1993, p. $5^{1 .}$

9 Thus, Alexander Murray is mistaken when he argues that 'A Letter of Remission, by definition, declared its beneficiary not guilty'. Rather, a letter of remission, like the remission granted by a priest to whom a person confessed, pardoned the beneficiary whether or not the beneficiary had committed the crime of which he or she was accused. Murray 1998, vol. 1, p. 207.

10 'voulans misericorde preferer a rigueur de justice anous[...]quicte remis et pardonne'. This exact phrasing may not appear in all letters, but it is a common choice to represent this sentiment, which is certainly present in all of them.

11 Texier 1999, p. 348. For more on the development of the legal concept of the king as emperor in his realm in the thirteenth century, see Voegelin 1997, vol. 3, p. 6 o.

12 During the reign of Charles $\mathrm{V}$, the definition of lèse-majesté was broadened to incorporate verbal as well as physical injuries to the king and to the rest of the royal line. See Hoareau-Dodinau 
The development of remission letters as an outlet for royal authority made them an increasingly central occupation of the king's chancery over time. While they began as a very small percentage of the chancery output (between 0 and 2 percent from 1304 to 1338), in the 1340 os there was a sudden increase in production such that they made up fully a quarter of the chancery records. In the 135 os the percentage rose to about half, then again to around three-quarters in the 1370 . The percentage held relatively steady at 75 , with a few spikes every ten years or so, when some books record 9o percent or more remission letters. The percentage of output did not fall until the 1480 s, when it began averaging half of chancery production again. ${ }^{13}$ Remission was limited to capital crimes, but during the height of the popularity of the letters they were granted for a wide range of criminal acts including counterfeiting currency, suicide, bestiality, theft, and rape, all of which could carry a death penalty but did not necessarily do so. There were attempts to limit the range of crimes for which remission could be granted, but apart from the exclusion of suicide from the mid-fifteenth century, these reforming efforts were largely unsuccessful until the sixteenth century, which is outside the range of this study. ${ }^{14}$

Several scholars have shown that, from the perspective of the king, remission letters demonstrated his jurisdictional power. Through granting mercy, the king exercised his ability to override the local legal traditions and the jurisdictional powers of both secular and religious lords. ${ }^{15}$ As a result, the letter itself was embedded within a language of royal power. Each letter

2002, p. 204. For examples of individuals who were granted remission after their compatriots were executed, see Cohen 1990, pp. 285-286.

13 The rest of the chancery documents are made up of ordonnances, letters of anoblissement, letters of naturalité, amortissements, concession or confirmation of privileges, and letters of abolition. For a table with the numbers of remission letters and the numbers of total acts, see François 1942. Although I found some of his counting to be questionable (particularly for AN $\mathrm{JJ} 189$ and AN JJ 204, where the number of remission letters exceeds the number of total acts), my own counting resulted in numbers close enough to his to allow these percentages to stand. Note that Claude Gauvard uses these same numbers to argue that the granting of remission letters decreased due to criticism in 1400. See the table in Gauvard 1991, vol. 1, p. 65. Although numerically it is true that there were fewer remission letters granted, I think this can be traced rather to lower chancery work during a time when France was suffering from civil war and English invasion. Remission letters remain a high percentage of chancery output during this time. In fact, the only true gap in the granting of remission appears between 1434 and 1441 (the gap occurs between AN JJ 175 and AN JJ 176), when Charles VII was in the process of taking Paris from the English.

14 Davis notes that in the sixteenth century the vast majority of letters of remission were for murder. Davis 1987 , p. 7 .

15 Gauvard 1991; Texier 2001; Texier 1999. 
began with the name of the king, 'by the grace of God, king of France,, ${ }^{16}$ and ended with formulaic language that reiterated the letter's function as a speech act that granted remission through the king's sovereign power. The letters operated as both written and oral acts of power, since they had to be carried back and read aloud in the local courts to be fully legitimized, thus transferring this notion of royal power from the center to the periphery. The letter was framed within an expression of the king's power, so that it simultaneously fulfilled the functions of pardoning a particular individual and, through the particular rhetoric of the letter, using that pardon to reinforce the king's sovereignty. For example, in a letter from 1387 composed on behalf of Robert Layné, a poor man whose madness caused him to say that he would fight anyone, including the king, Charles VI granted him remission by saying,

wishing to extend to him Our grace and mercy, We have assuredly considered these things. Desiring mercy to be [...] preferred to the rigor of justice, to this supplicant in the case above said we have acquitted, remitted, and pardoned all punishment and offense, criminal, corporal and civil that he has or could have justly incurred for the act and occasion of the said words, by him thus said, and through this present [letter] by special grace, full power and royal authority we do acquit, remit and pardon and restore him to his good reputation and renown in the country, and to his goods non-confiscated, and we impose on this [topic] perpetual silence in the present and in the future by Our procurer and by all our other officers. ${ }^{17}$

This coda, which is repeated in variations in every letter, expressed the power of the king to erase the criminal act committed by the pardoned individual. The irony of this reinforcement of kingly power embedded within a generous gesture of pardon for treasonous speech only increases its force. The king demonstrated his grace and mercy, which extended directly from his particular role as king of France by the grace of God.

16 'Par la grace de dieu, Roy de France'.

17 Saunier 1993, p. 498: 'nous lui vueillons eslargir Notre grâce et miséricorde Nous a de certes ses choses considérées voulans miséricorde estre miséricorde estre (sic) préférée à rigeur de justice à ycellui suppliant ou cas dessus dit toute peine offense criminele corporelle et civile qu'il a ou peut avoir encouru envers justice pour le fait et occasion des dictes paroles par lui ainsi dictes avons quitté, remis et pardonné et par ces présentes de grâce espécial pleine puissance et auctorité royal quittons, remettons et pardonnons et le restituons à sa bonne fame renommée au pays et à ses biens non confisquez et imposons sur ce silence perpétuel par Notre procureur présent et à venir et à touz autres noz officiers'. 
Perhaps the strongest evidence that remission letters were seen as a way of advertising power is the continuity of the granting of pardons. During the English 'occupation' of France, the chancery continued to grant remission on behalf of Henry, 'by the grace of God, king of France and England.' ${ }^{18}$ Jehannecte Troppé's letter was composed during this period. The dukes of Burgundy, further proving that the ability to grant pardon was seen as a significant part of the power of government, wielded this power in their own territories. ${ }^{19}$ Enclosed within this rhetorical expression of the king's sovereign power and majesty was the story of the particular crime the king had pardoned.

The path to any remission letter began with a crime. In Jehannecte Troppé's case, this would be the murder of Thomas Baillet. From this starting point, there were many possible peregrinations that would lead to the ultimate decision to seek the king's pardon. Sometimes, as happened to Jehannecte, the accused would have been imprisoned, and would either choose to acquire a letter before the trial took place or after having been found guilty. In other cases, the accused might have left town, essentially going into self-imposed exile, since medieval French courts considered flight as proof of guilt. ${ }^{20} \mathrm{~A}$ third possible route was preventive pardon, where the accused had neither been arrested nor fled the scene, but wanted to have the reassurance of pardon on the chance that the case might be pursued. Although some letters insisted on the innocence of the supplicant, most supplicants admitted to their guilt. The process of receiving the king's pardon was both time-consuming and expensive. First a petitioner had to travel to the king's council, which could be difficult, particularly for people who did not live in or around Paris, a fact reflected in the general geographic scope of the letters copied by the king's chancery. Indeed, the king's own travel impacted the letters received and ratified, since some letters relating to crimes committed many years before were recorded when the king happened to pass through the area. ${ }^{21}$ The king, or more likely an officer of the

18 See the letters collected in Longnon 1878: 'par la grace de Dieu roy de France et d'Angleterre'. See also those collected in Le Cacheux 1907-1908, vol. 1 .

19 For more on Burgundian pardons, see Arnade and Prevenier 2015, which also includes some edited and translated letters, though none pertaining to madness. More of the letters have been collected and edited (though not translated) in Petit-Dutaillis 1908.

20 Indeed, in this sense, remission letters act as a kind of 'passport', allowing the recipient to return. Much like medieval passports, the power was in the king's seal. For more on the development of the paperwork of identity, see Groebner 2007.

21 One of these, in AN JJ 99 fo 25 (in 1367 ), is a remission for a crime committed forty years earlier. The existence of these letters raises interesting questions about administration of the law in this period. If in some cases a person could commit a crime and then wait thirty years 
chancery, would then command a royal notary, together with the accused or the family members of the accused, to compose a letter explaining the circumstances leading up to the crime and telling the story of the crime itself. To be ratified, the letter had to be read before the king's council. Assuming it was satisfactory, the council would provide the remission seeker with a seal. For an extra fee, the letter would also be recorded in the official record by the chancery scribes, so that there was an external source proving the existence of the pardon. ${ }^{22}$ The price of the whole process was officially set at thirty-two Parisian sous in the fourteenth century: six for the redaction, six for the seal, and twenty for the registration in the chancery's books. ${ }^{23}$ This was more than a week's wages for most artisans, ${ }^{24}$ and although the king tried to control the price by passing ordinances, the ultimate tally could be much higher, particularly when the cost of a journey to Paris and accommodation while seeking pardon are added to the consideration. This was not the end of the process, however, since the petitioner had to return to the jurisdiction in which the crime had been committed and give the letter to the local administrator of justice. The letter would then be read aloud in the presence of the adverse party, who could be the bereaved family of a murder victim or the neighbors who brought the case to the attention of the court. If someone raised an objection the remission could be annulled, taking the accused back to the beginning. ${ }^{25}$

In theory, remission from crime was available to any criminal who had committed a capital crime, was able to bring his or her case before the king's council, and whose case appealed to the king's desire to practice lenient justice. In practice, remission letters had a number of overlapping goals which affected the rhetoric of the letter. The letter reflected the agendas of both the king and the individual seeking remission, each of which was refracted through the interpretive framework of the royal notaries who

before deciding to seek remission when the king was handily in the area, then what conditions were necessary for someone to be legally pursued?

22 Christian Gut 2000 provides a diplomatic study of the documents themselves.

23 Gauvard 1991, vol. 1, p. 68.

24 Geremek 1968, pp. 90-94. Geremek provides the day wages of masons, carpenters, and their assistants as an example, noting in one case from the early fourteenth century that masons and carpenters were paid 4 sous a day, while their assistants were paid 2 sous. He also notes that the day wages were seasonal, since the combined earnings of one carpenter and his valet in the late fourteenth century were 5 sous a day during summer, but only 4 sous a day during winter, presumably reflecting the change in available working hours as the days got shorter.

25 Some letters demonstrate this practice, since they appear in multiple versions in the chancery archives. 
wrote the letter down. ${ }^{26}$ Thus, there was no single author for a remission letter: it was a cooperative process. This was particularly true for remission letters for mad people, which were generally sought not by the accused but by their relatives and close family members. Jehannecte Troppé's letter, as noted above, was sought by her father and other relatives. The letters for the mad therefore reflect the multiple perspectives of the mad person's relatives and the scribe. It is more appropriate to think of these letters as 'composed' rather than 'authored'.

Historians have long recognized the value of remission letters, but until recently, most have mined the letters for anecdotal evidence, deconstructing the narratives in order to use them to construct other narratives. Natalie Zemon Davis's book about remission letters, Fiction in the Archives, focused scholarly attention on the ways these narratives about crime were constructed. ${ }^{27}$ Unlike the title of the work, which unfortunately has been misinterpreted by some scholars to mean these sources cannot be used by historians, ${ }^{28}$ the book itself does not seek to destroy the value of the texts but to focus historians' attention on their narratives, rather than on searching them for data. Like all historical sources, remission letters are not reflections of a factual reality that can be uncovered, but were constructed with a particular goal and include such information as is pertinent to that goal, formed into a coherent narrative thread. Although Davis never insists on the letters' fictionality as opposed to a possible 'true' event, she shows the ways in which these letters were written using familiar narrative devices that, to her, sprang from a shared knowledge of storytelling techniques. ${ }^{29}$ Brian Stock observes that 'stories do not convince us by their arguments but by their lifelikeness [...]. They may be verifiable, if we can get at the "facts"; but mainly they are believable'. ${ }^{30}$ The composers of remission letters would have been familiar with the process of creating a personal narrative of an event from storytelling and confession, which remission letters closely resemble. Where confession creates a moralized story within the context of an omniscient God, remission moralizes within the context of a king

26 Our knowledge of the royal notaries becomes significantly more complete in the seventeenth century, but for some details about them in the fifteenth century, see Lapeyre and Scheurer 1978, vol. 1, especially the introduction by Robert-Henri Bautier, ix-xxxix.

27 Davis 1987.

28 This became clear to me in the question and answer sessions of a number of conference panels in which I participated, when members of the audience were 'surprised' to learn that remission letters were not merely 'fiction in the archives'.

29 Davis 1987.

30 Stock 1990, p. 11. 
who provides justice, but could, like God, be convinced to temper it with mercy. ${ }^{31}$ It is essential to recognize and explore the ways in which these letters were constructed, who was involved in their redaction, and what kinds of discourses these composers pulled from to create their narratives.

More recent work on remission letters, particularly in France, has been influenced by Davis's focus on narratives, and has tried to understand these texts on their own terms. ${ }^{32}$ Claude Gauvard's study of letters from the fourteenth and fifteenth centuries focuses on the way that these narratives reflect social perceptions of crime and criminal behavior. Through statistical analysis of the letters, she demonstrates the relationship between particular social roles and types of crimes. ${ }^{33}$ Her evidence shows that madness was only used in one percent of remission letters. ${ }^{34}$ Gauvard notes that the actions of the mad as reported in remission letters 'contrasts sharply with normality', ${ }^{35}$ causing the close family and relatives involved in the remission letter to express astonishment; in her extensive study of crime she does not have space to analyze this astonishment or the behavior that elicited it, however. In looking at the treatment of madness in medieval English courts, Barbara Hanawalt similarly argues that '[a]ll the cases of mental disorder described in the rolls seem to have been the sort that would be readily recognizable to the average person: abnormalities as obvious as attempted suicide, bizarre behavior, and motiveless violence ${ }^{36}$ While I cannot speak for the English legal documents Hanawalt refers to, in the French remission letters I have examined, the violence is not always 'motiveless'. Indeed, a woman who attacks or even kills her husband because she believes that he was unfaithful, however wrong she may have been, does not seem motiveless to a modern reader. ${ }^{37}$ If the family of such a woman in the Middle Ages believed this

31 Hayden White sees historical narrative as intimately attached to moralizing. See Hayden White 1980. While others have challenged his assertion that moralism is the only grounds on which a narrative can be given a conclusion, notably Mink 1981, it is certainly true that the personal narratives in remission letters are intimately connected to a legal sensibility and a moralizing perspective.

32 See especially Gauvard 1991; Gauvard, 1995; Hoareau-Dodinau 1999; Saunier 1993; Texier 1999 .

33 Gauvard 1991.

34 Gauvard 1991, vol. 1, p. 436. My own research has confirmed this number. While Davis notes that madness was one of the eleven cases in which murder was pardonable by the king, she does not discuss how madness was elaborated in the letters of remission. Davis 1987, p. 12n.

35 Gauvard, 1991, vol. 1, 437: 'tranchent sur la normalité'.

36 Hanawalt 1979, p. 148.

37 There are several letters that revolve around spousal jealousy and madness, as I discuss in more detail below. See especially AN JJ 173 fo 33v no 63 (in 1425) (edited in Le Cacheux 1907-1908, 
kind of violent behavior had to be explained by the onset of madness, then it is interesting for the very fact that it would not be recognizable to the 'average person' today, but would have been to the 'average person' of the fourteenth century.

Annie Saunier's essay on madness in the remission letters does an excellent job of examining two particular letters, but her small sample size limited the kinds of observations she was able to make. ${ }^{38}$ The two letters she focuses on are both unusual cases. The first letter described a man who had gone mad from old age, recovered his sanity, and then had a relapse during which he murdered his wife. The letter is unusual in its brevity, disposing of the details of the case in seven lines of the manuscript, filling the rest of the letter with the rhetoric of the king's pardon. ${ }^{39}$ In the second letter, the mad man was rescued by local nobles who called in a physician to help him,$^{40}$ providing the only case out of the 155 letters I have examined where a physician's aid was sought for a mad person. Maud Ternon, whose chapters on remission letters draw extensively from my own research, is also focused on exploring the ways these narratives can show us what people thought about mental illness. Ternon's work provides an excellent overview, but she generally draws details from multiple letters rather than looking at the flow of an individual narrative in depth. ${ }^{41}$

Remission letters were detailed stories, carefully constructed to gain pardon without changing the perceived truth too much. Pascal Texier argues that remission letters, despite the royal notary's influence, express the 'subjectivity' and 'manner of speaking' of the supplicant. ${ }^{42}$ It is important to recognize, however, that, as with all legal records, these are not unmediated voices. Although the words of the supplicant are, indeed, present, they have been redacted to an appropriate form through a cooperative effort with the notary, who knew what kinds of questions to ask and what kind of information was necessary to the letter. Texier's hopeful reading of the

pp. 181-183); AN JJ 146 fo 83v no 162 (in 1394); AN JJ 173 fo 188v no 392 (in 1426) (edited mistakenly as JJ 175 no 392 in Longnon 1878, p. 208); and AN JJ 173 fo 168 no 349 (in 1425).

38 Saunier 1993.

39 AN JJ 130 fo 118v no 217 (in 1387), edited in Saunier 1993, 497-498.

40 AN JJ 131 fo 103 no 166 (in 1387), edited in Saunier 1993, 498-499.

41 Ternon 2018.

42 Texier elaborates 'à travers la mise en forme écrite par un clerc, c'est en tout premier lieu le point de vue du rémissionnaire qui est exprimé: ce sont donc sa subjectivité et sa manière de dire qui nous sont restitués pour l'essentiel. L'objet de la présente communication est donc d'analyser comment le rémissionnaire joue avec les concepts de responsabilité ou de culpabilité, et quelles stratégies il est amené à développer pour obtenir sa grâce'. 2001, p. 482. 
letters does not allow for the complexity of the interactions involved in the creation of these documents.

The narratives of remission letters each follow their own pattern to describe the individual's life. The terms used to describe madness and some of the themes of the narratives often follow familiar lines, but the letters are not formulae into which details are placed. Rather, each narrative was specific to the person about whom the letter was written, and created constructs of normal and transgressive behavior around which to describe the case. Composers of remission letters sought to create narrative coherence within the story of a particular person's life. While letters for sane criminals generally focused on the single day of the crime, letters for the mad often returned to earlier evidence of madness, describing the first remembered incidence of mad behavior and any others recalled in the intervening years.

The pattern of the genre of remission letters began to develop in the midfourteenth century. Certain information was considered necessary to the genre, while other structural elements were added over time. For example, only fifty-four of the one hundred fifty-five letters examined for this study included the age of the supplicant. By the mid-fifteenth century, although many of the letters still lacked the age, in some letters the royal notaries left a blank space where the age would normally appear in the composition. ${ }^{43} \mathrm{In}$ her examination of nineteenth-century settlement examinations under the English Poor Laws, Carolyn Steedman argues that from their inception in the seventeenth century, these 'enforced narratives' developed a formulaic pattern based on what was considered necessary information in describing the life of a poor servant for the purposes of determining whether or not he or she was eligible for poor relief in a certain village. ${ }^{44}$ The narratives produced conceal the process of question and answer that provided the necessary information, much as remission letters conceal the collaboration between notary and supplicant that together created the final product, in which certain information is considered necessary and other details are left out.

43 The earliest ones I found came from Charles VII's reign, in AN JJ 182-188. During the same period, other details also became part of the expected formula. AN JJ 187 fo $138 \mathrm{v}$ no $25^{2}$ (in 1455) leaves a blank for the town in which the supplicant lived, AN JJ 182 fo $51 \mathrm{v}$ no 86 (in 1453) leaves a blank for the day on which the events occurred, and AN JJ 199 fo 134V no 129 (in 1463), interestingly, leaves a blank space for the name of the man who was murdered.

44 Steedman 2002. Thank you to Kali Israel for pointing out how Steedman's work could be useful for my own. For a similar kind of construction of proof in the medieval period, see Rosenthal 2003. 
Because the letters enacted the king's mercy, some of the personal information about the supplicants was clearly intended to demonstrate their status as worthy recipients of that mercy. Many of them fit a particular mold of deserving supplicants described as 'poor' people, often 'laborers with their arms', who were responsible for their spouses, children, and sometimes aged parents. It was, of course, not always possible to fit each supplicant into this particular pattern, but all of them were described as being of bonne fame et renomée, or 'good reputation and renown', before the singular occurrence of the criminal act for which they sought remission. If the supplicant was not of good reputation before the particular crime, any other crime or infraction he or she was accused of had to be listed within the letter that then would note that the supplicant was of good reputation with the exception of those cases. ${ }^{45}$

The moment of crime acts as the climax of a narrative that humbly requests (although, because only successful letters were recorded in the chancery archives, in all the letters examined here this request has already been granted) the action of the king in a future moment outside the bounds of the narration. While the granting of remission is the intended end of the story within the text, it is not the only possible ending presented by the narrator, who envisions the likelihood of death in prison while awaiting trial, a trial that leads to execution, or a permanent, self-imposed exile. The moral thrust of the narrative is that the king's law is just but also merciful, and that, unlike his anonymously bureaucratic courts, he himself is willing to consider cases on an individual, personal level. In fact, this distinction is purely rhetorical, which must have been eminently clear to the king's subjects during periods of regency, particularly the regency for Henry, the English king, who was a baby at his coronation. Instead of indicating a personal acquaintance with the woes of his subject, the French king's granting of remission was in fact the bureaucratic royal system functioning in full force. ${ }^{46}$

Many of the letters composed for mad people began from the rhetorical premise that they were not written from the perspective of the mad criminal. Instead, in most cases, letters for mad people came from their parens et amis

45 This most often occurred within letters written for soldiers, who sought remission for a long list of campaign-related crimes, such as looting, pillaging, and raping. This is true in several of the earliest letters of remission, which can be found edited in Jassemin and Vallée 1999.

46 Bernard Guenée has argued that Charles VI's madness cemented the administrative powers of the government, which was forced to find a way to represent the king's majesty without the king himself. He notes that '[l]a maladie de Charles VI a appris au royaume à vivre, ou plutôt à survivre, tant bien que mal, sans le roi, en exultant la royauté'. Guenée 2004, p. 262. 
charnels, which can be translated as their 'relatives and immediate family', according to Claude Gauvard's examination of the terms. ${ }^{47}$ Even in those cases where criminals seeking remission claimed to have been mad at the time of the act but sane when applying for the king's mercy, they used the language of madness to emphasize the difference between their 'normal' behavior and their behavior while out of their senses. Letters for the mad, then, were at a rhetorical level even further removed from the event they purported to describe than the majority of remission letters, which were written from the perspective of the sane criminal.

\section{Languages of Madness from Families and Notaries}

Most remission letters give no clear indication of the social status of the remission seekers, but those that do exhibit a broad social range, from beggars and manual laborers to merchants and nobles. ${ }^{48}$ Many of those identified in the letters according to profession were skilled artisans, including butchers, bakers, barrel makers, and carpenters. The majority of supplicants were identified simply as laborers, often 'poor' laborers. With some exceptions, it is unlikely that these remission seekers would have been educated, and very few would even have been literate in French. The supplicants would have been familiar with a number of methods of constructing a narrative, however. The tradition of storytelling, the requirement of yearly confession, and the sermons and saints' lives read to them by their priests all provided exempla for creating a coherent tale.

In contrast, the notaries who wrote the letters down and helped compose them were not only literate but Latinate. ${ }^{49}$ Since the royal notaries were often trained in law and remission letters were part of the greater legal system in France, legal questions were central to their construction..$^{50}$

47 Gauvard 1991, vol. 2, pp. 643-651.

$4843 \%$ of the letters provide some indication of status, and these are randomly scattered throughout the $15^{\circ}$ year period covered by this study, with no suggestion of change over time in terms of the frequency with which social status was mentioned nor in terms of the status of remission seekers.

49 Many were university-trained, and some were canons before their career in the royal chancery. Information about the careers of fifty-one royal secretaries and twenty-four royal notaries under Charles VI, fifteen of whom overlap, can be found in the online database, 'Opération Charles VI,' (Laboratoire de Médiévistique occidentale de Paris). Ten out of the sixty men listed were canons, and many of these held multiple ecclesiastical positions.

$5^{0}$ Mireille Desjardins, in a discussion of royal notaries in the fifteenth century, notes that 'Outre la langue et l'écriture latine et française, ils doivent connaître les droits coutumiers et romain, 
Some notaries were officially licencie en lois ('licensed in law'), many were ennobled by the king for their service as royal notaries, and a few rank among the famous French humanists of the fourteenth and fifteenth centuries, including Gontier Col and Jean de Montreuil, famous for their debate with Christine de Pizan on the subject of the Roman de la Rose..$^{1}$ Often the positions were passed down from father to son or through other family connections, as genealogical studies of the notaries from later periods show. ${ }^{52}$ Jean de Rinel, who helped compose Jehannecte Troppé's letter, was the nephew by marriage of Pierre Cauchon, Bishop of Beauvais, who was also chaplain to the Duke of Burgundy. Jean's position as a royal notary for the English court in France was gained partly through the Bishop's influence, and he acted as scribe in 1429, when his uncle-in-law prosecuted Joan of Arc. ${ }^{53}$ In addition to their work in the royal chancery, the fifteenth century saw a particularly important flowering of notarial writing in literary and political arenas, and Jean de Rinel was involved in this extension of notarial works. His most significant work in this arena was his 1435 treatise defending the Treaty of Troyes against those who claimed that Charles VI's madness invalidated it. ${ }^{54}$ Jean de Rinel, then,

les ordonnances royales et la jurisprudence qui s'appliquent au royaume afin de comprendre les consequences légales des documents qu'ils rédigent'. Desjardins 1997, p. 88. See also Lapeyre and Scheurer 1978.

51 See Gauvard 1997, p. 288. For the documents from the debate between these notaries and Christine de Pizan, see McWebb 2006.

$5^{2}$ Unfortunately, the most extensive studies of the identities of the royal notaries begin in the reign of Louis XI in 1461, towards the end of the period studied here. See Lapeyre and Scheurer 1978.

53 At Joan's trial, where Jean de Rinel acted as notary, there was no attempt made to explain Joan's visions in natural terms. Her accusers ignored the theoretical framework provided by medical treatises. Her visions, they claimed, 'proceeded from lying, evil spirits, rather than from good; and everyone should treat them as such, especially considering her cruelty, pride, haughtiness, actions, lies, and contradictions'. The full focus of the theological attack on Joan centered around her pact with the devil. Unlike Jehannecte Troppé, whose family could slide easily between one explanatory frame and another, Joan of Arc's accusers found it necessary to establish only one truth, since their case against her rested on proving she was demonically, not divinely, inspired. Hobbins 2005, 125-138. Pierre Champion included a brief biographical sketch of Jean de Rinel in his edition of Joan of Arc's trial, Champion 1920-1921, p. 338 .

54 In 1435, Jean de Rinel wrote a treatise defending the Treaty of Troyes, in which he concentrated on the natural effects of King Charles VI's madness. Chaplais 1982, pp. 650-651. Many notaries composed political treatises as part of their work in the chancery, most of which, as Craig Taylor argues persuasively, were intended to be distributed to each other for facilitating diplomatic missions and the creation of new treaties. Particularly as Charles VII's campaign grew more successful in the 1430s, notaries worked to prove that the Treaty of Troyes was not legally sound, 
can act as a particularly adept guide through the complex relationships that royal notaries had with the concept of madness. Bearing in mind that these letters were carefully constructed by a group of composers, and the resulting narrative had to be acceptable to all parties involved, how did the notaries and the family members work together to tell these stories? Only a small percentage of the letters mention madness (one percent of the total), but these provide compelling evidence for the ways in which it was defined and interpreted.

Faced with the task of explaining Jehannecte Troppés murder of her husband, Jean de Rinel coordinated with her family to find a way of narrating the story that focused on her aberrant behavior leading up to the moment of the crime. The letter deployed multiple terms to establish that behavior as caused by mental imbalance. According to Jehannecte Troppés letter, in October, more than two weeks before she killed her husband, Jehannecte had begun seeing visions that made her believe her husband had left her alone at night and caused her to become 'merencolie'. The next day, she acted as if she were 'demoniacle', and her husband recognized that her actions came from 'frenaisie et merencolie', or possibly from 'mal du saint', 55 and did not punish her for them, hoping that soon she would return to her 'bon sens et advis'. Unfortunately, she did not, and on the fateful night when she killed her husband, she again saw a 'vision' and 'par temptacion mauvaise de l'ennemi' she beat him with a rock. Afterwards, 'non sachant qu'elle faisoit ou disoit' she did not run away but rather stayed with her spouse without understanding that she was guilty of injuring him. Her relatives indicated that she was still, two months later, 'comme demoniacle', and due to her 'maladie' should not be punished for her crime, adding that she should be released from prison, not only for her own health but for the health of the

focusing on the mental state of Charles VI as part of their arguments. As Craig Taylor argues, the polemical works generally appear in very few manuscripts and contain cross-references to treaties contained in the chancery archives in an effort to aid those notaries and secretaries of the king sent on diplomatic missions. Taylor 2000, p. 216. In this he is mostly arguing against scholars like P.S. Lewis, who insist on reading these treatises as propaganda pieces intended for a wider audience. Lewis 1965, p. 217. Jean de Rinel had been part of the delegation sent to negotiate the Treaty of Troyes in 1420 , and was probably the notary assigned to copy the text, since his name was attached to it, thus giving him an intimate knowledge of the text itself as well as of the negotiations leading up to it. For more on his relationship to Pierre Cauchon and his participation in the Treaty of Troyes, see Neveux 1987, p. 70. Neveux also includes a genealogy for Cauchon, which lists Jean de Rinel's children and their professions, including one canon and a greffier (following in his father's footsteps).

55 'Mal du saint' could be understood as an illness visited on someone as punishment for offending a saint. See Briggs 1989, p. 24. 
child she was carrying. Finally, they cited the customary laws of Normandy, asserting that, if released from prison, Jehannecte would be kept in chains or otherwise securely guarded so that she would not harm anyone else in future..$^{6}$

The religious, literary and political spheres in which the notaries interacted with each other and with other intellectuals may not have often had a direct impact on their work in the royal chancery, but in a case like Jehannecte Troppé's, Jean de Rinel was able to bring to bear his own knowledge about different types of visionary experiences in offering a possible vocabulary for her family's letter. The story they constructed reveals the variety of terms available in French to describe a mental disturbance that could lead to violence. The range of words and phrases used in describing Jehannecte Troppé suggest some of the complexities and confusions involved in describing an internal state that could be recognized through behavioral signs. The composers of Jehannecte Troppé's letter of remission, like many others writing on behalf of people whose actions had been interpreted as mad, included a number of different terms to describe her behavior. Wendy Turner and Irina Metzler have both attempted to create taxonomies of terms for madness in medieval texts. ${ }^{57}$ While the sources they focus on support such rigid lines between definitions, the composers of remission letters rather seem to pick from a grab bag of possible terms without worrying too much about the kinds of careful distinctions made in more theoretical discourses. There are certainly continuities across the discourses that addressed madness, and some of this common ground was reflected in the understanding of madness in these letters. Although the use of these terms suggests an awareness of wider discourses about madness and its meanings, the letters seldom fully engaged with any of these larger conceptual frameworks. Particularly because these letters were not dependent upon any single discourse, they can be used in aggregate to establish a lexicon of madness..$^{8}$

56 AN JJ 173 fo 33v no 63. Edited in Le Cacheux 1907-1908, vol. 1, pp. 181-183: 'melancholy'; 'demonically possessed'; 'frenzy and melancholy'; 'illness of the saint'; 'good sense and vision'; 'vision'; 'by evil temptation of the enemy [Satan]'; 'not knowing what she did or said'; 'as if possessed by a demon'; 'illness'. The customary law of Normandy does call for the chaining or guarding of the mad to prevent their harming themselves or others. Gruchy 1881, p. 184 LXXIX. See my discussion of the law codes below, in Pfau 2010b, and in Pfau 2008, chapter 3.

57 Turner 2013b; Turner 2013a, pp. 17-29 and p. 69; Metzler 2016, pp. 31-52.

$5^{8}$ For an important list of terminology used in English sources, see Turner 2013a Appendix I, pp. $233^{-238}$. 
Table 1 Terms

\begin{tabular}{llllll}
\hline Terms & $\begin{array}{l}\text { Number of } \\
\text { letters }\end{array}$ & $\begin{array}{l}\text { Total } \\
\text { Frequency }\end{array}$ & Terms & $\begin{array}{l}\text { Number of } \\
\text { letters }\end{array}$ & $\begin{array}{l}\text { Total } \\
\text { Frequency }\end{array}$ \\
\hline Sens & 70 & 84 & Lunatique & 5 & 5 \\
Fol & 51 & 53 & Cognoissance & 5 & 5 \\
Malade & 32 & 32 & Raison & 4 & 4 \\
Fureur & 29 & 34 & Enragie & 2 & 2 \\
Entendement & 28 & 29 & Altere & 2 & 2 \\
Frenaisie & 19 & 19 & Aliene & 2 & 2 \\
Memoire & 18 & 18 & Caduque & 2 & 2 \\
Simple & 15 & 15 & Sot & 2 & 2 \\
Idiot & 12 & 12 & Cervel & 2 & 2 \\
Melancholie & 11 & 11 & Estonne & 2 & 2 \\
Savoir & 10 & 10 & Affoible & 1 & 1 \\
Forsene & 8 & 14 & Fatuite & 1 & 1 \\
Desespere & 8 & 8 & Esmouvance & 1 & 1 \\
Estourdi & 6 & 6 & Insane & 1 & 1 \\
Ignorance & 6 & 6 & Teste & 1 & 1 \\
Demoniacle & 5 & 5 & Dyable & 1 & 1 \\
& & & demens captui & 1 & 1 \\
\hline
\end{tabular}

Note that the total number of letters examined is 155 .

There are two main types of language that composers of remission letters for mad people used. There was the negative language implying a loss of some cognitive ability, or the more complicated idea of being 'outside' it. Most often the loss or externality referred to the 'sense', 'understanding', 'memory', or 'knowledge'. The composers could also choose from a wide range of adjectives or nouns, each of which was recognizably part of a discourse of madness, including 'frenzied', 'furious', 'melancholic', 'demoniac', and 'foolish' (see Table 1). On average, the letters used two completely different terms, but some letters had as many as seven, suggesting that the composers were aware of the range of terminology available to describe what they perceived as mad behavior. The terms sens, fol, fureur, and entendement were sometimes involved repeatedly in a single letter, perhaps indicating that they were particularly resonant words. In their attempts to find a conceptual vocabulary about madness, the composers of remission letters had a number of different cultural resources from which to draw. The language used to describe madness in remission letters varied widely. The composers drew from many of the available discourses, creating a fluid vision of what madness was. Through a process of collaboration, the mad person's family members told their story to the royal notary, who translated 
it into a framework that would make sense to the family, the king's council, and ultimately the adverse party.

\section{Notaries and Literary Circles}

Beginning in the mid-fourteenth century, Charles V supported a large-scale translation project that sought to make French an intellectual language equal to Latin. The literary debate about the Roman de la Rose provides a vivid snapshot of the repercussions of this effort, as well as of the larger intellectual community in which the royal notaries took part. The Roman de la Rose survives in over 300 manuscripts and has been called one of the most read works of the Middle Ages. ${ }^{59}$ Certainly it was one of the most contentious. Those involved in the debate drew on an extensive knowledge of philosophy, law, theology, literature, and especially classical authors. The participants, many of whom have been seen as France's earliest humanists, included important fifteenth-century theologians from the University of Paris, such as Pierre d'Ailly and Jean Gerson; literary figures at court, particularly Christine de Pizan; and the royal notaries Jean de Montreuil and Gontier and Pierre Col. ${ }^{6}$ Claude Gauvard, in an article about the royal notaries, notes that 'the letters signed by Gontier Col or Jean de Montreuil do not stand out from the quality of the rest. These humanists reserved their genius for epistolary relations that were less constraining!' ${ }^{11}$ While this is certainly the case (and indeed one would not expect otherwise in terms of rhetorical exuberance), the notaries' intellectual exploits nevertheless had an impact on their knowledge of and interest in particular subjects.

Jean de Meun expanded Guillaume de Lorris's brief Roman de la Rose between 1270 and 1280, around forty years after the original author's death, as Jean de Meun claimed. He turned the text into a philosophical allegory, where personifications of virtues and vices sought to instruct the Foolish Lover (Fol Amoureux) towards his goal of capturing the Rose, symbol of a woman's maidenhead. The Roman's Foolish Lover wandered through a landscape filled with allegorical figures spouting classical authorities and examples before finally possessing his Rose. Two of these figures, the

59 Guillaume de Lorris and Jean de Meun 1992, p. 5 .

6o There is a vast literature on the relationships between these participants. See Combes 1973, Coville 1934. More recent work has been concerned with Christine de Pizan in addition to the men, particularly Huot 1993 .

61 Gauvard 1997, 288: 'des lettres signées Gontier Col ou Jean de Montreuil ne tranchent pas sur la qualité de l'ensemble. Ces humanistes réservent leur génie à des relations épistolaires moins contraignantes'! 
Jealous Husband and the Duenna, proved particularly troubling to Jean de Meun's critics. The Jealous Husband claimed that no woman was pure and cursed the whole sex, while the Duenna proved these words by offering her services as a go-between for the Lover and Fair Welcome, whom he wished to woo into giving him access to his Rose. The Roman raised philosophical questions of whether words were inherently bad and whether it was legitimate for an author to write from the perspective of a morally questionable person. At one moment in the text, the figure of Reason described love as a paradox: 'C'est reson toute forsenable / C'est forcenerie resnable' ('It is reason completely mad / It is madness reasonable'). ${ }^{62}$ In this formulation, the author was drawing upon two possible understandings of madness. ${ }^{63}$ First, madness was presented as a corruption of reason, and a loss of sense or wisdom. At the same time, the text developed the Biblical inversion that will be discussed below, where folly could appear as reason and wisdom, and vice versa. Interestingly, reason appears relatively rarely in the remission letters, only being used four times, while the different variations on forsene appear fourteen times in eight different letters. As we shall see, this latter term was drawn from the legal discourse with which royal notaries would have been very familiar.

The response to the Roman began with the political question of French supremacy, since it filled the role of representative of the French language in humanist circles, much as Dante's Divine Comedy did for Italian. Petrarch, for example, argued that 'orators and poets were not to be sought outside of Italy, ${ }^{64}$ In this sense, then, the defense of the Roman de la Rose was an integral part of the larger project of promoting French as an intellectual language in which philosophical concepts could be expressed and explored. In 1401, Christine de Pizan shifted attention to women's social and political roles, a particularly potent area of debate at a time when the Hundred Years War made Salic Law central to Valois legitimacy. ${ }^{65}$ The debate about language, focused both on the relationship between signifier and signified

62 Guillaume de Lorris and Jean de Meun 1992, p. 282, ll. 4296-4297 and 1. 4320.

63 Forsené was also used in other medieval literary texts. Tobler and Lommatzsch 1925-, vol. 3, pt. 2, pp. 2146-2149.

64 Petrarch, Seniles 9.1: 'oratores et poete extra Italiam non querantur'. Quoted in McWebb 2006, p. 2.

65 After the death of Charles IV of France, there were serious questions about the succession. The French chose to invoke Salic Law, which declared the French throne could not be inherited through a woman. This meant that Edward III, the English King and son of Isabella (daughter of the Capetian French King), was not a legitimate heir to the French throne, and the Valois cadet branch was instead. This was one of the key factors that led to Edward's war against the French that developed into the Hundred Years War. 
and the question of voice (in other words, whether a moral person should write immoral things if they are written in the character of an immoral person), was especially pertinent in 1401, since Charles VI had passed a law making blasphemy a crime punishable by death. ${ }^{66}$ Language mattered, and the questions of who was speaking in a text, the author or a character, and of whether a word could be morally bad of itself or whether words were naturally good and only the object could be morally bad, held philosophical weight. Indeed, this question may have seemed particularly compelling to the royal notaries, who engaged daily in the composition of narratives from the perspective of self-confessed criminals. Perhaps it is unsurprising, then, that these notaries were so firm in their defense of Jean de Meun's Roman.

While Jean de Montreuil and Gontier Col both wrote private letters in praise of Jean de Meun, and in response to his critics, neither chose to directly enter the public debate with Christine de Pizan, instead placing that challenge on the shoulders of Pierre Col, Gontier's brother. Jean de Montreuil sent a letter to Gontier Col in late July or early August 1401, calling upon Gontier to aid his defense of Jean de Meun and saying,

it will be up to you as the leader, prince, and director of this undertaking to defend such a praiseworthy and beloved imitator, and to tread underfoot these sick and mad [malesanos et deliros] [critics] and to strengthen, arrange in order, and overlay my half-baked reasonings with the sharpness of your eloquence, inasmuch as I, relying on the confidence of your help and the wealth of your genius, have entered this battlefield, something I would otherwise not have done. ${ }^{67}$

Since Gontier Col was responsible for introducing Jean de Montreuil to the Roman de la Rose, Jean argued that he was justified in seeking his friend's aid in defending the work. The imputation of madness to the critics of the Roman is telling, particularly since Jean de Montreuil uses the word delirus, with its connection to delirious and raving madness. Although the negation

66 Stein 1908, pp. 153-154; Vilevault and Bréquigny 1763, vol. 10, p. 243.

67 'Quorum pretextu in alterum istorum patronorum scriptotenus invexi, sicut videbis per eam quam tibi fert epistolam is baiulus. Tuum ergo erit, dux, princeps rectorque huius cepti, laudatissimum et amatissimum imitatorem tuum defensare, et hos malesanos et // deliros conculcare ac ratiunculas meas indigestas disertie tue acumine validare, comere et linire, quatenus ego, qui auxilii tui confidentia ac ingenii ope fretus, campus hunc duelli introii, alias non facturus. Scio enim quod ubi obdormientes tui sensus expergiscentur, et calamus iacens excret se, 'non prevalebunt adversus nos' isti veritatis inimici, sed eos, cum voles, non dubito efficies oves mittes, et mutos reddes per omnia tanquam truncos.' McWebb 2006, pp. 208-209. 
of the term sens was the most commonly used phrase to describe madness in remission letters, malesanos (the concept of bad sense) does not appear at all, nor does there appear to be a direct translation of delirus. Clearly these notaries were aware of and comfortable with the use of the literary and symbolic languages of madness and lovesickness. When composing letters of remission, they certainly did not display their literary abilities nor did they draw from the same vocabulary, but nevertheless, the larger intellectual communities to which they belonged influenced their concepts of narrative structure and their concerns about language.

Another active member of these humanist circles, Laurent de Premierfait, had a number of connections with the French court. He engaged in correspondence with several humanist royal notaries while he was living in Avignon at the papal court. When he moved to Paris, he worked as a clerk for one of the king's secretaries, which would have brought him into even closer contact with the royal court. Laurent de Premierfait was translating, and expanding upon, Giovanni Boccaccio's De Casibus Illustrium Virorum (The Fall of Noble Men), making it available to a French audience in the vernacular under the title Des cas des nobles hommes et femmes. In 1400, he translated the work directly, but in 1409 he revised the original, returning to the classical sources and expanding considerably on Boccaccio's original. When he finished his revised version, he was working as secretary to Jean, duke of Berry, uncle to King Charles VI, and patron of a number of important works of literature and art. ${ }^{68}$

In Laurent de Premierfait's 1409 retelling of the story of Cadmus, king of Thebes, the king's family members play a central role in his downfall. ${ }^{69}$ The first disruptive episode in Cadmus's life involved his daughter. As Laurent told the story,

while the women of Thebes were, according to their custom, performing the festival of Bacchus, Agane, daughter of the said Cadmus, became insane [forsennee] and went to the court as if enraged [enraigee] against her son Pantheus, whom she had had with Echion her husband, a noble and powerful man. And Agane struck and murdered her son Pantheus who had mocked the sacrifices that were done to Bacchus, the god of

68 For more on Laurent de Premierfait's life and works, see the essays collected in Bozzolo 2004 .

69 This was Laurent de Premierfait's second translation of Giovanni Boccacio's De Casibus Virorum Illustrium (The Fall of Noble Men). The story of Cadmus in both Boccaccio and Laurent de Premierfait was drawn from Euripides' play, The Bacchae. See Boccaccio 1962, p. 31; Euripides 2001. 
wine, and as some people say she murdered him with a javelin or a club while the said Pantheus was not thinking of anything; thus as Agane, returning to her senses [sens], afterward heard it told..$^{70}$

Agane, becoming forsennee and enraigee, created ruptures within her family, and attacked those she would normally hold dear. These terms appear rarely in remission letters (forsene in eight and enragie in two). On the other hand, the concept of being outside of and returning to one's senses appears in seventy letters (forty-five percent of the total). Pantheus had mocked the sacrifices of the Bacchanal, which placed Agane's act in the context of a challenge to her religious community. While in ordinary circumstances Pantheus's challenge would not have led his mother to such a violent anger, the impetus of the ritual of the Bacchanal pushed her beyond her normal behavior, making her 'enraged'. The pathos of the passage is highlighted through both the emphasis on Pantheus's identity as Agane's legitimate son and Pantheus's lack of fear or concern when his mother appeared. Significantly, much like Jehannecte Troppé, Agane lost her memory of her own actions while she was 'insane', requiring others to tell her about her own deeds when she returned 'to her senses'. Her memory loss further confirmed the altered state in which she had murdered her child, and created a need for a narrative reconstruction of events that allowed Agane and her family to explain and comprehend the horror of her son's death.

Agane's actions were not the only violent episode in Cadmus's family. In a second occurrence, the husband of another of Cadmus's daughters also attacked his children. ${ }^{71}$ Laurent explained

Athamas, son-in-law of Cadmus, who was already called king of Thebes and to whom the people did honor as if he were already king, became enraged [enraigié] and crazy [sot], to such an extent that Athamas, believing that his wife Ynoe, daughter of the said Cadmus, was a lioness and that

70 Gathercole 1968, pp. 123-124: 'tandiz que les femmes de Thebes faisoient selon leur coustume les festes de Bachus, Agane fille du dit Cadmus devint forsennee et s'en vint le cours comme enraigee contre son filz Pantheus lequel elle avoit eu de Echion son mari, noble et puissant homme. Et Agane frapa et murtry son filz Pantheus qui se moquoit des sacrifices que l'en faisoit a Bachus, le dieu du vin, et comme aucuns dient elle le murtri d'un javelot ou d'une massue tandiz que le dit Pantheus pensoit en riens, ainsi comme Agane retournee en son sens oy aprés racompter'.

71 This story was drawn from Ovid's Metamorphoses. See Ovid 2004, pp. 140-146. Note that, although madness ran in the family here, it was not attributed to heredity, since Agane and Athamas were not related by blood, only by marriage. 
his two small children were two lions, gave a great cry. And afterwards, by force, he grabbed Learcus, their son together, out of the arms of Ynoe, and knocked and broke [the child] with all his effort against a hard rock. But immediately Ynoe, the mother of Learcus, upset at his death, fearing for Meleatrix, another of her sons, and fleeing Athamas, her husband, who followed her, maddened [forseneux] and enraged [enraigié]; she threw herself, with her said son Meleatrix, off the crest of a mountain into the Ionean Sea, and because of this she and her son were swallowed up and died in that sea. ${ }^{2}$

These two moments of violence have clear parallels, as both Agane and Athamas destroy the next generation, erasing Cadmus's lineage as well as their own. The terminology Laurent de Premierfait used to describe this madness, these mental states in which such violent actions were possible, carries over from one event to the other. Athamas, like Agane, was described as enraigié and forseneux. Their mental states were not identical: Athamas was also described as sot, a word that appears in only two of the remission letters related to madness (though drunkenness does appear in many other letters). Athamas' behavior manifested itself in terms of visions, rather than religious ecstasy. His visions were distinct from Jehannecte Troppés as he saw his family transformed into wild animals rather than imagining their absence. Nevertheless, in both cases the focus was on a transformation of the normal into the frighteningly strange, both for the sufferer him- or herself and for the family members who did not expect to be the target of his or her aggression. These literary representations constructed a dichotomy between the expected behavior and the actual behavior of the subject, who destroyed communal and familial relationships by attacking the very people that he or she logically should protect.

In contrast to Laurent de Premierfait's expansion of the work, Boccaccio's treatment of Cadmus's violent and mentally unstable relatives was truncated, and used less varied and evocative language. In his Latin version, Agane was

72 Gathercole 1968, p. 124: 'Athamas, gendre de Cadmus, que l'en surnommoit ja roy de Thebes et auquel le peuple fasoit honneurs comme se il feust ja roy devint enraigié et sot, en tant que Athamas, cuidant sa femme Ynoe fille du dit Cadmus feust une leonnesse et que ses deux petis enfans feussent deux leonceaux, fist un grant cri. Et aprés par force il arracha de entre les bras de Ynoe Learcus leur commun filz, et le quoti et froissa de tout son effort contre une dure roche. Mais tandiz que Ynoe la mere de Learcus courroucee de sa mort doubtoit de Meleatrix un sien autre filz et fuyoit Athamas son mary qui la poursuivoit forseneux et enraigié, elle avec son dit filz Meleatrix se trebucha de la creste d'une montaigne en la mer Yonie, et par ainsi elle avec son filz fut transgloutie, et mourut en celle mer'. 
'furiis agitata' when she killed her son, and Athamus 'in furorem lapsus. ${ }^{73}$ Laurent de Premierfait's translation thus moved beyond the simple image of fury, seeking multiple terms to describe Agane's and Athamas's madness. These vernacular French terms suggested particular contexts within which these moments of mental instability could be understood.

In 1409, stories about madness, kingship, family and community such as Laurent de Premierfait's would have had a particular resonance for French readers. Charles VI, the French king, had turned on his own men in 1392, in an episode his contemporaries believed was caused by a mental disturbance, and the king continued to suffer unpredictable relapses. ${ }^{74}$ Indeed, as Nigel Mortimer has argued, citing the illustrations in the manuscript tradition, 'the De casibus narratives of the fallen figures of mythology, the Bible, antiquity, and recent history appear to have been used in France to comment on the political events of the present'. ${ }^{2} \mathrm{Du}-$ cal patronage from the king's uncle widened Laurent's audience beyond his own humanist circles to the court itself, where his treatment of the madness of kings and princes would certainly have been read in the light of the potential tragedies inherent in Charles VI's own illness. Both the literary and political significance of languages of madness would have been recognized by the royal notaries, who engaged in a similar process of searching for appropriate French terminology to help them describe the condition of these remission seekers.

\section{Medicine and Natural Philosophy}

The single most common word used to indicate madness in remission letters is the negation of the word sens. This concept of madness as a negation of cognitive ability drew upon medieval medicine and natural philosophy. What did it mean to be hors du sens, hors d'entendement, hors du memoire, or all three? The medical knowledge available to the average person in the Middle Ages was not particularly complex, but it is clear from the remission

\footnotetext{
73 Boccaccio 1962, p. 31.

74 For more on the French King's madness and its representation in chronicles, see Pfau 2008, Chapter 2; Guenée 2004; Famiglietti 1986; Autrand 1986. A recent book by Julie Singer has explored the ways contemporary literary texts used the language of machines and metal to think creatively about mental health in the context of the king's madness. See Singer 2018, especially pp. $79-172$.

75 Mortimer 2005, p. 34. He points out that one manuscript version includes an image of Charles VII presiding over the trial of Jean, duke of Alençon, accused of conspiracy with the English and executed.
} 
letters that some general ideas of illness and health were shared commonly ${ }^{76}$ The royal notaries were not likely to be trained in medicine, but their understandings of the body would have been more informed by medical theory than those of the people seeking remission. Certainly, they would have been aware of the medical terms available to speak about madness. As part of the emerging professional classes, the royal notaries had a number of links to physicians in the late Middle Ages. For example, Christine de Pizan was the daughter of a royal physician and the wife of a royal notary. These kinds of marriage ties were not unusual, but perhaps more significantly for the question of language, several royal notaries owned medical texts, including some in translation. Jean de Montaigu, notary and secretary for Charles VI, owned a copy of the French translation of Bartholomaeus Anglicus's On the Properties of Things. In the section on the brain, the book explains the Galenic understanding of cognitive processes. This involved a tripartite model of the brain, where imagination (ymaginacion) was in the warm and dry front, reason (raison) in the warm and moist middle, and memory (memoire) in the cold and dry back..$^{77}$ Thus, the areas of the brain also correspond to three of the four humors (only phlegm is left out), with imagination associated with choler, reason associated with blood (a sanguine nature), and memory associated with melancholy. ${ }^{78}$

Isidore of Seville, in his sixth-century Etymologies, used the tripartite model of the brain to provide a model of mental illness under the heading of Chronic Diseases, dividing the general category of madness into three specific types: epilepsy, mania, and melancholy, which arise from imagination, memory, and reason, respectively. ${ }^{79}$ Bartholomeus Anglicus followed this same effort to tie types of madness to different areas of the brain, but for him, mania (manie), otherwise known in medical discourse as amance, was an injury to the imagination, melancholy (melancolie) was an injury to the reason, and lethargy (litargie) was an injury to the memory. ${ }^{80}$ Regardless of which illness was linked with which part of the brain, this division allowed for a more complicated reading of behavior to explain disturbances believed

76 Pouchelle examines Henri de Mondeville's fourteenth-century Chirurgie as a central piece from which to extrapolate about the metaphorical world of the body in the Middle Ages. See especially her discussion of methodology, Pouchelle 1990, pp. 95-100.

77 British Library (henceforth abbreviated as BL) Additional 11612 fo $53 \mathrm{v}$. See also Harvey 1975, p. 35; Klibansky, Panofsky, and Saxl 1964, pp. 68-69.

78 Wendy Turner has a helpful exploration of the location of different types of mental illness in the brain. See Turner 2013a, pp. 66-76.

79 Isidore of Seville 1911, IV.7; Isidore of Seville 2006, p. 111.

80 BL Additional 11612 fo $104 \mathrm{v}$. 
to be caused by madness. Problems with the imagination generally produced visions, problems with the memory caused forgetfulness, and problems with the reason caused people to do irrational things. ${ }^{81}$

According to humoral theory, madness, like any other disease, was caused by an imbalance of the humors, but particularly an extreme excess of any one of them. Thus, madness could result from an increasingly serious case of another disease. In this sense, the illness was understood to be physiological. Although madness was concentrated in the brain, where they believed the mind was located, physicians also saw it as a disease that affected the entire body of the individual. One common perceived cause of madness in remission letters was illness, often a fever that made the person act in unexpected and inexplicable ways, or a blow to the head that caused temporary or permanent damage to a person's brain..$^{82}$

A fever or other disease was often mentioned as the source of a temporary madness that led in many cases to suicide..$^{83}$ Interestingly, illness could even be seen as a legitimate catalyst for suicide without the addition of madness, as it was in the case of Jehan du Puy, who was purportedly on his deathbed due to illness in 1420 . He had made his will, confessed, and received extreme unction before cutting his own throat. The composers of his letter explained his actions by suggesting he committed suicide because of 'temptation of the enemy, because of the oppression of his illness, or from some other cause', ${ }^{84}$ but they did not suggest madness as an excuse. Other letters, in contrast, focused particularly on the ways in which illness could lead to a frenetic or melancholic state that made the person in question no longer responsible for any action.

The mental repercussions of being hit on the head were well understood in the Middle Ages, and in fact often the temporary results of being estourdie, or 'stunned', were used as an explanation for questionable actions in tavern brawls. ${ }^{85}$ It was also understood that getting hit over the head hard enough could cause lasting damage, as was the case for Guillaume Audoyn, who

81 Klibansky, Panofsky, and Saxl 1964, p. 93. See also the chart of the Aristotelian division of souls in Park 1988, p. 466.

82 This is also apparently true in records of medieval English law courts dealing with criminal cases. Butler 2015, pp. 199-200.

83 Thirty of the one hundred forty-five letters examined mention a 'maladie', either as the original source of the madness or as an integral part of the madness.

84 AN JJ 171 fo 94V no 156: 'pour ce que par temptacion de lennemj pour cause de loppression de maladie ou autrement il sest coppes la gorge en commectant homicide de lui mesme'.

85 See the references to becoming 'estourdie' after a blow to the head in AN JJ 220 fo $227 \mathrm{~V}$ no 380 (in 1489); AN JJ 209 fo 55 no 93 (in 1480); AN JJ 199 fo $317 \mathrm{~V}$ no 502 (in 1465); AN JJ 131 fo $39 \mathrm{v}$ no 69 (in 1387); AN JJ 172 fo 113v no 221 (in 1422); and AN JJ 173 fo $250 v$ no 524 (in 1426). 
had fallen off a ladder in 1403 and hit his head. Guillaume was considered 'sourt', 'insensible', and 'ydiot' for two years before any thing serious occurred. Indeed, he was capable of continuing to perform manual labor, since disaster struck while he and his wife were loading manure onto a cart. He believed she was mocking him with her movements, and 'because he was stupid and idiotic through lack of sense, angered and incensed' he knocked her over with his pitchfork and hit her several times, then drove away with the cart. ${ }^{86}$

Medical texts described four distinct types of madness: frenzy, mania, melancholy, and lethargy, each of which corresponded to an excess in one of the humors. ${ }^{87}$ Avicenna's work on melancholy made it the source for all types of madness, breaking down the separation of the humors and explaining that all four humors, when burnt, could turn into melancholy. Each type of burnt humor created a particular type of madness, however, with blood creating joy and laughter, phlegm creating sloth, yellow bile creating frenzied violence, and black bile creating 'great thoughtfulness and less agitation and frenzy except when the patient is provoked and quarrels, or nourishes a hatred which he cannot forget'. ${ }^{88}$ Of these four categories, only frenzy and melancholy appear in the remission letters.

The term frenaisie appeared in nineteen letters, more than any of the other types of madness described in medical texts. This term almost always appeared alongside multiple other terms, most commonly paired with sens or maladie. In fact, at times an illness was imagined as turned into a frenzy, as was the case for Denisot Sensigaut, whose 'illness of heat' caused him to 'cheu en frenoisie'. ${ }^{89}$ Interestingly, in three letters it appears alongside melancholie, suggesting that the composers of remission letters were less concerned with differential diagnosis than with using terms that were

86 ANJJ 160 fo 70v no 91, edited in Guérin 1909, vol. 7, pp. 80-82: 'deaf'; 'insensible'; 'idiot'; 'pour ce qu'il estoit sourt et ydiot par non sens, yré et courroucé de ce'.

87 According to Hippocrates' De Morbo Sacro, which Jean-Marie Fritz argues was influential for thinking about madness in the Middle Ages, frenzy and lethargy included fever, while mania and melancholia did not. This instability, according to Fritz, made mania and, especially, melancholia the focus of medical discourse in a way that frenzy and lethargy were not. Fritz 1992, pp. 133-138. However, more recently Julie Laskaris has suggested that it was not in fact known in the Middle Ages, noting 'there is no evidence that On the Sacred Disease was translated into Latin, so its transmission into the medieval tradition is obviously in doubt. Its reception in the Renaissance and later seemed to center not on the rational premises it brought to medicine but, ironically, on the high degree of proper religious sentiment it proved that Hippocrates had expressed'. See Laskaris 2002, p. 60.

88 Avicenna, Liber canonis, quoted in Klibansky, Panofsky, and Saxl 1964, pp. 88-89.

89 AN JJ 171 fo $244 \mathrm{~V}$ no 429, edited in Longnon 1878, pp. 19-21: 'maladie des chaleurs'; 'fall into a frenzy'. 
recognizably medical. The earliest letter to combine these two terms was the one composed in 1425 for Jehannecte Troppé, described above. The second was from 1459 and was written on behalf of Jacquet Morniet, a fifty-year-old man who had been suffering from a 'maladie' and 'melencolie' that had made him 'fort frenaisieux et altere de son entendement et blecie en son cerveau' for about a year before he committed murder..$^{90}$ The letter combined multiple terms and phrases from medical discourse, explaining that the melancholy illness had injured his brain, causing him to become frenzied and altered in his understanding. Finally, there is the 1474 letter written on behalf of Jehanne, the wife of Chrestien Bolu, who after giving birth to her daughter entered into a 'melancolie' because they were too poor to support their family. This melancholy made her 'insensee' so that she decided to drown herself and her children 'en ceste fureur frenaisie et toute hors du sens et entendement'. ${ }^{11}$ Again, the letter is drawing from a number of different medical terms without distinguishing between them.

Frenesie appears in the earliest vernacular health treatise, the thirteenthcentury Le Régime du corps by Aldobrandino of Siena. He warns against sleeping on one's back 'por ce qu'il fait maintes maladies venir, si com apoplesie, frenesie, fantosme' ('because it makes many illnesses come, such as apoplexy, frenzy, phantasm')..$^{22}$ The word appears in a number of non-medical texts as well. For example, in Gautier de Coincy's Les Miracles de la sainte Vierge, he lists 'li frenetiques, Li fors du sens, li enragiez' together, indicating that medical and literary vocabularies were not mutually exclusive in religious texts, and suggesting a larger pattern of cross-pollination. ${ }^{93}$ Indeed, frenesie also appears in literary texts. In Adenés li Roi's Li Roumans de Cleomadès, he explains that torment and illness 'lassaillirent si Que en frenesie chëi' ('assail him such that he falls into frenzy'). ${ }^{94}$ This language of 'falling into frenzy' created an image of madness as a descent. In contrast,

9o The victim in the case was Jacquet's brother's wife Jehanne, who lived in the extended household along with their parents and children. Jacquet's illness had seriously limited his participation in household tasks, and his sister-in-law began to berate him one evening for his refusal to help his mother, calling him a 'mean man' who 'is worthless'. His anger, combined with his illness, caused him to lash out against her, picking up a pestle and hitting her over the head. AN JJ 188 fo 102 no 203: 'illness'; 'melancholy'; 'very frenzied and altered in his understanding and injured in his brain'; 'ung meschant homme et quil ne valoit riens'.

91 AN JJ 195 fo 268v no 1204: 'melancholy'; 'insensible'; 'in this furor, frenzy, and completely outside her sense and understanding'.

92 Cited in Tobler and Lommatzsch 1925-, vol. 3, pt. 2, p. 2236.

93 Tobler and Lommatzsch 1925-, vol. 3, pt. 2, 2236: 'those frenetics, those outside their senses, those enraged'.

94 Cited in Tobler and Lommatzsch 1925-, vol. 3, pt. 2, 2236. 
use of the term melancholie often involves 'fullness', suggesting a surfeit of black bile or an excess of melancholic emotions. In the late thirteenthcentury romance, Sone de Nausay, for example, one character laments, 'Je suis sans sens, sans vaillandie, Et plains de grant melancolie' ('I am without senses, without valor, and full of great melancholy'). ${ }^{95}$ In Chrétien de Troyes' Chevalier au lyon, Yvain is helped out of his melancholy through the power of massage: 'Tant li froia au chaut soloil Les tanples et trestot le cors Que cel cervel li issi fors La rage et la melancolie' ('She rubbed so well in that hot sun His temples and his whole body That from his brain issued all The rage and the melancholy'). ${ }^{96}$ Again, there is a suggestion of fullness, where the melancholy and rage filled his brain and must therefore be removed in order that he return to his balanced state, and a connection between mental disturbance and emotion, as rage and melancholy were both also associated with the passions.

For the most part, this choice to use medical terms without a clear understanding of differential diagnosis is not surprising. Royal notaries were knowledgeable about the law but did not generally have medical training. However, there is a copy of Jacques Despars's commentary on Avicenna's Canon in the British Library that was owned by the royal notary Jean Budé, who worked for Louis XI in the late fifteenth century and was an important book collector. ${ }^{97}$ Jacques Despars composed his commentary, which as Danielle Jacquart asserts, reads more like a collection of his own exemplum loosely arranged around Avicenna's work, between 1432 and $1453 \cdot{ }^{98} \mathrm{In}$ book three, Avicenna discusses the signs of melancholy and includes a list of things that melancholics irrationally fear, such as the sky falling on them, the earth absorbing them, or being attacked by robbers or wolves. Jacques Despars's commentary includes a fascinating anecdote about a 'notable and famous' Parisian melancholiac (melancholicus) in his own time, who had an incessant fear that he would be arrested and beheaded and another about a monk who was so melancholic that he tried to throw himself out of windows. ${ }^{99}$ While there was little effort made in remission letters to distinguish between different types of mental illness terminology, it is clear that these anecdotes about irrational fears and suicide attempts were part of common knowledge about what it meant to be mad.

Cited in Tobler and Lommatzsch 1925-, vol. 5, 1353 . 
The term melancholy appears in eleven different letters, including the three discussed above. Its use spiked in the 1420s, with four of the eleven letters dating from that decade. Much like frenzy, melancholy often appears alongside other words. The most common were sens and entendement, but malade, folie, and fureur appeared as often as frenaisie. One particularly interesting letter combined seven different terms. Composed on behalf of Colin Tanquart in 1415, it described him as a young man between sixteen and eighteen who, about three years earlier, began to become diminished in his 'entendement' which made him 'furieux, ydiote, ou insensee'. More recently he had fallen into 'malencolyes par sotie et folye'. ${ }^{100}$ The inclusion of multiple terms that, according to theoretical literature, would not be used to describe the same state, is particularly interesting here. ${ }^{101}$ In his madness, the young Colin would paint 'fantastic' things on a large shield, then stare at them and attack the shield. According to his father, Colin continued to go to school even as his condition worsened until one night he hanged himself in the small room where he usually slept. His father found him the next morning when he went to wake him up to go to school.

Bartholomeus Anglicus's On the Properties of Things explained that 'the head is sometimes sick because of things that are within it, like the passions which arise in the brain such as frenzy [frenaise], epilepsy [epilancie], and their like.. ${ }^{102}$ Bartholomeus Anglicus discusses the kinds of diseases that might affect the brain as well. He notes that the brain can retreat into itself, such that 'it does not obey as well the virtues of the soul as it appears in those who are lunatics [lunatiques] and in those who fall from the high illness [hault mal]. ${ }^{103}$ The 'high illness' was sometimes also referred to as caduc or falling sickness, which one André Guibretea suffered from in 1404, causing him to have episodes during which he became 'furieux et fol'. ${ }^{104}$ Bartholomeus Anglicus also notes that lunatics are more troubled when the moon is new or full than at other times.

100 AN JJ 168 fo 231v no 344: 'understanding'; 'furious, idiotic, or insensible'; 'melancholy due to stupidity and folly'.

101 Irina Metzler, in particular, has established the careful categorization on the part of medieval intellectuals differentiating between what she calls congenital intellectual disability and acquired mental illness. See Metzler 2016, especially chapter 2.

102 BL Additional 11612 fo $52 \mathrm{v}$ : 'Le chief est aucune fois malade par cause qui est dedens lui sicomme des passions qui naissent du cervel sicomme sont frenaise epilancie et leurs sanblables'. 103 BL Additional 11612 fo $53 \mathrm{v}$ : 'ne obeit pas si bien ala vertu de lame si comme il appert en ceulx qui sont lunatiques et en ceulx qui chieient du hault mal'.

104 AN JJ 158 fo 168 no 36o, edited in Guérin 1909, vol. 7, pp. 38-41: 'furious and foolish'. 
When the brain is too dry or too moist, this causes 'the illness of small understanding [petite dentendement] ${ }^{105}$ Bartholomeus Anglicus has a section on frenzy in which he lists a large number of French terms related to madness. He explains:

In the $28^{\text {th }}$ chapter of the book of Deuteronomy, it says that God sometimes struck people with forsenerie and with folie and with esbahissement, forsenerie is in this sense called frenaisie on which Constantine said that frenaisie is an aposteme that is between the skins of the brain that makes the person age and go out of his senses. And it is called frenaisie for the skins of the brain which are called fresnes as Constantine says. ${ }^{106}$

Here, the text uses a large number of different terms for madness, including forsenerie, mostly used in French legal texts, to help the reader understand the specialized medical term frenaisie. He also opens with a reference to the biblical text of Deuteronomy, which uses the Latin words amentia, caecitate, and furore mentis to describe the kinds of madness with which God might curse people. Though caecitate, as Bartholomeus Anglicus notes later in his text, translates as blindness (avugleire), he nevertheless explains it as a kind of blindness of reason. ${ }^{107}$

\section{Law}

Roman law tended to use the language of furiosus and furor to describe the kind of violent madness that might lead to criminal actions. The French vocabulary was significantly more varied, though by far the most common term used in French customary law codes was forsené, a translation of furiosus. The use of forsené is surprisingly rare in the remission letters; instead, they more commonly chose to use fureur or furieux. These terms were often used alongside multiple others, and indeed twice they were used together, once in 1376 and once in 1380 . The letter from 1376, written on behalf of Pierre de Solente, who had murdered his nine-year-old son, used six different terms to describe his madness, explaining that he had

105 BL Additional 11612 fo $53 \mathrm{v}$ : 'maladie de petite dentendement'.

106 BL Additional 11612 fo 103v: 'Il est contenu ou xxvijje chapitre du livre deutronomie qui dieu fiert bat aucunes fois les personnes de forseneire et de folie et de esbahissement forseneneire est en ce propos appellee frenaisie de laquelle dit constantin que frenaisie est une apostume qui est entre les peaulx du cervel qui fait la personne veillier et yssir du sens. Et est appellee frenaisie pour les peaulx du cervel que on appelle fresnes sicomme dit constantin'.

107 BL Additional 11612 fo $104 \mathrm{v}$. 
become 'ydiote', 'furieux', and 'desespere' such that he had previously tried to commit suicide. He committed the act in his 'forsenerie' without 'senz ne memoire'. ${ }^{108}$ The terms are similarly used alongside a large range of additional possible words in the 1380 case of Jehan de Moustier discussed in detail in Chapter Two. There they are used with five additional terms: 'maladie' 'insensible, 'folie, 'simosite,' and 'navroit memoire'. Interestingly, forsenez is used in the full phrase 'imbue de maligne esprit en sa dicte forsenerie', suggesting a supernatural explanation in addition to the natural one. ${ }^{109}$

The earliest use found for the term forcenez is in a blasphemy case from 1364, and it seems not to carry very much weight. The baker Jehan Razochez claims to have blasphemed because he was 'forcenez de grief' in response to the taxes he had to pay. His madness had no further effect on him, at least as recorded in the letter. ${ }^{110}$ Later cases use the term in much more serious ways, often alongside additional language describing the madness. For example, in an infanticide case from 1379, Phote Brumel was so upset when her daughter had an illegitimate baby with their coachman, thus potentially ruining her plans for an advantageous marriage, that she became as if 'hors du sens' and threw the baby into a well 'corrociee et forsenee'. ${ }^{111}$ Another use of the term appears in a letter that pulls from five different linguistic possibilities thrown into a single sentence. The case, also from 1379, involves Jehannecte Marchant, a young married woman guilty of theft who 'na pas bon sens naturel souvent et est merencolieuse et de forcenerie [...] par la folie' steals. ${ }^{112}$ In a case from 1394, the term is used to describe a woman who 'comme forsenee et oultrageuse' got drunk, stayed out late, and was killed by her husband. ${ }^{113}$ In a case from 1400 , it was also used to describe a woman who had gotten drunk and was momentarily 'surprins et chargiee de vin, toute forcenee et temptee de lennemy' so that she committed suicide by strangling herself. ${ }^{114} \mathrm{~A}$ case from 1403 recorded by the same notary describes Jehannecte de la Forge who was often 'forcenee et desmuee dentendement

108 AN JJ 110 fo 125 no 108: 'idiot'; 'furious'; 'despairing'; 'fury'; 'sense nor memory'.

109 AN JJ 118 fo 18v no 18: 'illness'; 'insensible'; 'folly'; 'stupidity'; 'has no memory'; 'filled with a malign spirit in his said fury'.

110 AN JJ 98 fo $36 \mathrm{v}$ no 114: 'maddened by grief'.

111 AN JJ 114 fo 116v no 236: 'outside her senses'; 'angered and maddened'.

112 AN JJ 115 fo 52 no 114: 'often does not have good, natural sense and is melancholy and from madness [...] by the folly'.

113 AN JJ 146 fo 24 no 55 : 'as if mad and outrageous'.

114 AN JJ 155 fo 168 no 276 : 'surprised and filled with wine, totally mad and tempted by the enemy [Satan]'. 
raisonnable et de tout sens et comme forcenee et hors de sens' and cut the throat of her granddaughter. ${ }^{115}$

The legal landscape of late medieval France was a patchwork of competing and cooperating judicial systems. The canon law of the Church was accepted throughout France, ${ }^{116}$ but the jurisdictions of bishops and archbishops often uneasily competed with royal justice. ${ }^{117}$ In general terms, southern France had adopted the system of Roman law, ${ }^{118}$ while northern

115 ANJJ 158 fo 11 no 20 : ' $m a d$ and diminished in reasonable understanding and in all sense and as if mad and out of her senses'.

116 Medieval canon law crossed national borders and, theoretically at least, applied equally to all levels of society throughout Christendom, from the lowliest peasant to kings and emperors. In practice, of course, this was not the case; but, as James Brundage points out, the theory of a universally applicable law was a fascinating development even if it was not practicable. Brundage 1995, p. 3. Canon law had its foundations in the early Church, with the earliest surviving pamphlet of Church law dating from the first or second century A.D. Over time, the laws proliferated, with many decisions apparently contradicting others. In the early eleventh century, Burchard of Worms proposed that the context of each law be considered to resolve these conflicts, but it was not until Gratian's Decretum, composed around 1140, that an attempt was made to provide such resolutions. For a brief exploration of the history of medieval canon law, see Brundage 1995. For more detail, see Kuttner 1935 and Wintoth 2000. For more on the practice of canon law, see the essays collected in Brundage 2004. Gratian's project was an effort to synthesize the laws, providing 'an authoritative guide [...] that would permit judges and administrators to find their way through the tangled underbrush of the law with reasonable certainty and at tolerable speed'. Brundage 1995, p. 43. It presented the legal considerations dialectically, highlighting the disagreements between different decisions, but choosing one as the better alternative or determining the circumstances in which each decision had merit. As a result, Gratian's compilation became a favorite teaching text, and was thus familiar to students of law throughout Europe.

117 Nicole Gonthier has shown this in her study of Lyon. Gonthier 1993, especially pp. 19-44. This could also be true in individual cities, which were occasionally divided between the bishop's law and the local lord's law. For a rich archival study of one of these towns, see Wroe 1995.

118 Medieval knowledge of Roman law came mostly from the Corpus iuris civilis, which was composed of the Institutes, the Digest, the Code, and the Novels, all of which were compiled during the reign of Emperor Justinian in the sixth century A.D. The Institutes, produced in 533 A.D., consists of an elementary guide to Roman law, modeled after an earlier (and surviving) version dating from 160 A.D. The Digest was compiled between 530 and 533 , and essentially gathered together the opinions of classical Roman jurists and organized them according to topics. The different jurists did not always agree with each other on each topic, but there was no attempt made on the part of the compilers to provide a single, unified response to the question under consideration. Instead, the goal of the Digest was to provide multiple authoritative voices addressing the same questions. Papinian, Ulpian, Modestinus, and the Laws of the Twelve Tables are the sources cited in reference to madness. The Laws of the Twelve Tables is the earliest known source for Roman private law, promulgated around 450 B.C., but only surviving in those fragments collected by later compilers. The Twelve Tables consisted of a list of legal rules, and most of what survives was concerned with family law, property, succession, and the rules for legal process. Papinian, Ulpian and Modestinus, all jurists in the third century A.D., wrote extensive commentaries on questions directed to them. These commentaries, as excerpted 
France acknowledged customary law, which was regionally determined and could even vary between urban centers and the countryside. The legacy of both Roman law and canon law is evident in the compilations of French customary law when it began to be recorded in the thirteenth century. Customary law was understood as an oral tradition that drew on local memory, and as distinct from Roman and Canon law by virtue of the fact that it was not codified. As Esther Cohen argues, the myth of customary law as 'old,' 'good,' and 'pure,' specifically because of its orality, led practitioners to avoid writing down the laws until well into the thirteenth century. ${ }^{119}$ In 1454 , towards the end of the period under consideration here, the French king issued an ordinance calling for the redaction of all local customs, and when this process was completed by the middle of the sixteenth century they had been standardized to some degree, ensuring that they did not conflict with any royal ordinances. The earlier redactions of customary law, their authors often attest in their prologues, were intended to instruct those who were not knowledgeable about the law. The customals considered here are just such instruction manuals, and although a few of them were originally written in Latin, all of them have vernacular versions. ${ }^{120}$ I have looked at the ways that

in the Digest, have been removed from their original context and placed next to each other. While this facilitates reference, it also makes it difficult to know whether the jurist's opinion is case-specific or intended to have wider ramifications. The compilers of the Code, released in 534 A.D., were specifically instructed to provide a synthesis of laws, unlike those who assembled the Digest, and to avoid including repetitious, contradictory, or obsolete laws. The final section of the Corpus, the Novels, comprises a collection of new laws that were created during Justinian's reign, but none of them refers to madness. For more on Roman law, see Johnston 1999, pp. 2-3, pp. 12-14, pp. 22-23.

119 See Cohen 1993, pp. 28-39.

120 See especially the prologue of Jacques d'Ableiges 1868, pp. 4-6. Many customary law books did not mention madness at all, leaving open the question about how that region legally coped with mad people. See, for one example, Marechal and Poumarede 1988. In those customals that do refer to madness, the influence of Roman law can often be detected, but they depart from Justinian's Corpus in significant ways. The texts under consideration for their reference to madness are mostly from the thirteenth century, although there are two later redactions as well. The earliest is the Très-ancien Coutumier de Normandie, found in both Latin and French manuscripts from the early thirteenth century. Tardif 1903, vol. 1. In the later thirteenth century, another version of the customs of Normandy was redacted, known as the Ancienne Coutumes de Normandie. Gruchy 1881. Philippe de Beaumanoir was heavily influenced by Roman law in his redaction of the Coutumes de Beauvaisis composed around 1283. Philippe de Beaumanoir 1970-1974, vols. 1-3; Philippe de Beaumanoir 1992. A final thirteenth century legal compilation is Li livre de jostice et de plet from the region of Orléans, a compilation of Roman, Canon, and some customary laws. Rapetti 1850. Jacques d'Ableiges composed his Grand coutumier de France, a compilation of customary law from the Île de France, at some point in the fourteenth century. 
Roman and customary law addressed questions of mental competence in terms of guardianship and contractual agreements elsewhere. ${ }^{121}$ Here, I am interested in focusing on the language used in French to describe madness in terms of crime. Following the tradition of Roman law, French customals argued that the mad should not be punished for criminal actions.

The earliest of the customals comes from Normandy and uses varied language to talk about potentially violent madness. The Ancienne coutume de Normandie made provisions for mad people under the heading of 'On Suicides'. Suicides were punished severely under French law. Their goods were confiscate to the crown, their bodies were often 'executed', and they would be buried in unconsecrated ground, having forfeited their right to inclusion in the community of the faithful. However, the Norman customal recommended that

any mad [forsené], enraged [enragié], or frenetic [frénétique] person is not to be driven out of the community of the church, in such a case where at the time when he was well ordered in his thoughts, he carried himself as a good Christian; nor are the goods of these forfeited [to the king], if by any mischance they have been killed; but it belongs to the prelate to organize the goods of these, because they [the mad] do not have the understanding to organize them [their goods]. ${ }^{122}$

Here the customal uses a number of different French terms to refer to madness, rather than simply using forsené. Both of the additional terms come from medical language and refer to a kind of active and chaotic madness. The idea that the suicide of a mad person was accidental (by 'mischance') removes any culpability, so punishment would be inappropriate if the individual in question had been 'a good Christian' while sane. This judgment parallels that of Thomas Aquinas, who determined that mad people were still able to receive baptism and the Eucharist if, when sane, they were

Jacques d'Ableiges 1868. And finally there is a mid-fifteenth-century customal from Anjou and Maine. Beautemps-Beaupré 1883 , vol. 4.

121 Pfau 2010 b and Pfau 2008 , chapter 3.

122 Gruchy 1881, pp. 56-57, XXI: 'Et aulcun forsené, enragié, ou frénétique n'est à oster de la communie de l'Eglise, pour tant au temps qu'il estoit bien ordonné de sa pensée, il se portast bon Crestien; ne de ceulx n'est pas le chastel forfaict [au Roy], se par aucune malefortune ils ont esté occis; mais appartient au prélat à ordonner d'iceulx chastels, puisqu'ils n'ont sentement pour en ordonner'. 
believers. ${ }^{123}$ Reputation, not only as a mad person but also as a Christian, played a significant role in determining the treatment of the accused. ${ }^{124}$

Philippe de Beaumanoir, writing his Coutumes de Beauvaisis around 1283 , made a distinction between the 'naturally mad', or fous natureus, and the 'insane', or forsenés, noting that 'one cannot sue on an agreement made by $[. .$.$] an insane person, nor a natural mad person [...] for [...] neither$ an insane person nor a natural mad person [can make an agreement], because they do not know what they are doing.' ${ }^{125}$ Although he saw these as two distinct conditions, he nevertheless discussed them under the same circumstances. ${ }^{126}$ Philippe de Beaumanoir also suggested that neither should be punished for their crimes, but here, interestingly, he chose to use a different terminology. He suggested that if 'they commit, because of their mad senses [folsens], a homicide or any other serious crime, they are not punished like others because they do not know what they are doing'. ${ }^{27}$ Instead of being punished 'like others,' for example by being executed for committing a capital crime like homicide, Beauvaisis's customary law called for the imprisonment of the mad person after a crime was committed.

The thirteenth-century Livres de jostice et de plet from the region of Orléans, adds a new term to our list, one which does not appear in any of the other texts. This term, desverie, is used in conjunction with the usual legal term forsené. The text explains that, when faced with a mad person who had committed a crime,

123 Aquinas responded to the argument that the mad are like beasts and therefore should not be given the sacraments by saying that ' $[\mathrm{m}]$ admen and imbeciles lack the use of reason accidentally, i.e. through some impediment in a bodily organ; but not like irrational animals through want of a rational soul'. Aquinas 1981, vol. 4, pp. 118-120. For the Latin, see Aquinas 1964, vol. 57, p. 120, 3a 68,12 .

124 Interestingly, the Norman customal recommended that the mad person's goods be organized by the church, since clearly a mad person would not have been capable of making a will. This opens up interesting possibilities for clashes between the officers of the crown and local prelates in suicide cases, since the crown would benefit from those found sane and the Church would benefit from those found mad, although it is not possible here to do more than speculate.

125 Philippe de Beaumanoir 1970-1974, vol. 2, ch. 34, paragraph 1061: 'L'en ne puet suir de convenance $[\ldots]$ forsené, ne fol naturel [...] car [...] ne li forsenés, ne li fous natureus pour ce qu'il ne sevent qu'il font'. See also vol. 1, ch. 12, paragraph 411.

126 Here I take issue with the work of Irina Metzler, who argues that the distinction between these two conditions is more significant. Metzler 2016.

127 Philippe de Beaumanoir 1970-1974, vol. 2, ch. 52, paragraph 1575: 'il font par leur fol sens aucun homicide ou aucun autre vilain cas, il ne sont pas justicié en la maniere des autres pour ce qu'il ne sevent qu'il font'. 
if you know certainly that he did it in madness [forsenerie], that he does not know what he does every day, and that he understands nothing, nor is there any suspicion against him, you can in a way alleviate his sentence, because he is tormented enough by his madness [desverie]. ${ }^{128}$

A lack of understanding and knowledge of 'what he does every day' suggests a lack of intent and therefore of responsibility, but the jurist recommends that the sentence should be alleviated, not because of the mad person's lack of intent, but because his madness is sufficient torment. While this may be merely a rhetorical aside without much impact on the legal treatment of mad criminals, it reveals an interesting tension between the acceptance that mad people should not be held responsible for their crimes and the belief that criminal acts deserve punishment regardless of intent. ${ }^{129}$

Underlying the concept that mad people could not be held responsible for criminal acts was a larger philosophical tradition that determined the importance of intent. For example, in his French translation of Aristotle's Ethics, a copy of which was owned by the royal notary Jean de Montaigu, ${ }^{130}$ Nicole Oresme ${ }^{131}$ used the term forsené in his translation of a passage about intent, noting that 'dumb beasts who do not have any use of reason or intention or understanding, nor children or mad people [foursenez] who do not have the use of reason and do nothing intentionally'. ${ }^{32}$ Though Oresme

128 Rapetti 1850, p. 73, XXI.5: 'Et se tu sés certainement que il l'ait fet en forsenerie, qu'il ne sache qu'il face toz jorz, et qu'il n'entende riens, n'en i ait point de sopeçon contre lui, tu porras en une feintise estramper sa paine, quar il est assez tormentez de sa desverie'.

129 This may in fact be related to the medieval practice of punishing animals for crimes, despite their lack of comprehension. As Jacqueline Hoareau-Dodinau points out, 'la sanction infligée par le group social à la suite d'un acte qui trouble la communauté n'est pas automatiquement liée à la notion de responsabilité au sens juridique du terme, c'est-à-dire aux notions de faute, de volonté, de liberté. Pour répondre à un crime, le groupe peut exercer une vengeance sur le coupable, écarter un danger qui le menace en éliminant l'auteur ou se purifier de la souillure résultant de l'acte sans pour autant envisager la notion de responsabilité; c'est-à-dire envisager la répression par rapport à la victime ou au groupe auquel elle appartient et non pas au égard au coupable'. Hoareau-Dodinau 2001, p. 192. See also Cohen 1993, pp. 101-133.

130 Holbrook 2006, pp. 380-381.

131 Oresme was a fourteenth-century philosopher, mathematician, and theologian commissioned by Charles V to translate a number of Aristotle's works. For a brief biography of Oresme, see Babbitt 1985, pp. 1-4. See also the brief addition to his early biography in Courtenay 2000.

132 BL Egerton 737 fo 56 : 'les bestes mues qui nont point usaige de raison ne voulente ne entendement ne les enfans et foursenez qui nont pas usaige de raison ne font riens voluntairement'. For more on the philosophical development of the theory of intentionality, see the essays collected in Perler 2001. 
regularly chose to translate terms related to madness by using forsené, he also often used the phrase hors de bon sens. For example, in Book 7 , Chapter 5 on incontinence, the text explains that some men cannot control themselves, like those who sleep and those who because of an illness are out of their good sense [na pas bien son sens]'. Oresme also provides a glose which explains the text, saying 'some who are called amoureux or amer par amours such that they are mad and are ill from a sickness that the physicians call amorcerois. ${ }^{\prime}{ }^{133}$ This terminology of lovesickness does not appear in letters of remission, but as noted above phrases like hors de bon sens or na pas bien son sens were very common.

Starting in the fourteenth century, French legal texts began to use the word fol to describe potentially violent madness. For example, Jacques d'Ableiges' fourteenth-century Grand Coutumier de France listed 'when any crime is done by any mad [folle] or drunken person' among a number of other reasons for altering the proscribed sentence, indicating that intent was the significant factor, since neither drunk people nor mad people are capable of intent. ${ }^{134} \mathrm{~A}$ mid-fifteenth-century customal from Anjou and Maine also explained that 'a mad person [ $\mathrm{fol}$ ] who kills or mutilates a man or a woman should be kept in prison perpetually at his or her own expense. But for theft [possibly rape?] or another small crime, his or her madness excuses it'. ${ }^{135}$ Thus, although madness could be seen as an excuse for a 'small crime', it did not excuse murder or mutilation. Even though the customal provided an alternative (and lighter) sentence for mad people, it emphasized that some form of punishment was necessary for attacking another person.

Use of the words fou and folie in letters of remission often indicated behavior similar to that described by the English terms 'fool' and 'folly'. ${ }^{136}$ The term was only rarely used on its own, rather than in conjunction with other terms evoking madness, most often in cases of theft or rape.

133 BL Egerton 737 fo 189: 'Si comme cellui qui dort et cellui qui par la cause de maladie na pas bien son sens.' 'Si comme aucuns que lendit amoureux ou amer par amours entant quilz en afolent et sont malades dun mal que les medicins appellent amorcerois'.

134 Jacques d'Ableiges 1868, p. 649 IV.xii 'Des peines': 'quant aucun excès est faict par aucune personne folle ou yvre'.

135 Beautemps-Beaupré 1883, p. 268: 'Le fol qui occist ou mutille homme ou femme doit à ses despens estre tenu en chartre perpetuelle. Mais pour embler ou faire autre petit excès, sa folie l'en excuse'.

136 See for example AN JJ 223 no 41 fo $24 \mathrm{~V}$, where a drunken man is described as 'foul'; AN JJ 209 no 93 fo 55 , where a drunken man uses the term 'foulx' as an insult; AN JJ 155 no 11 fo 5 , where a young man steals from 'folie'; and AN JJ 155 no 309 fo 188, where young men commit gang rape through their 'folie jeunnesse'. 
So, for example, a 1379 letter composed on behalf of Ysabelet de Baconne explained that she had stolen from her uncle, with whom she lived, to give to her lover because of her 'foleur' and her youth. ${ }^{137}$ In other cases, the same terms were used as one of the array of possible terms to describe a more violent form of madness. A bar brawl in 1390 that led to murder involved Pierre Chambo 'dit le fol'. In addition to being called fol, the letter composed on his behalf noted that he was 'comme tout ydiote non aiant senz ne discrettion'. When he lost a great deal of money while gambling with Pierre Audrieu, called Tachat, they took their argument outside. Tachat came at Chambo with a knife, but Chambo, who had no knife or sword, killed Tachat by hitting him in the head with a stone. The composers of the letter insisted that this happened because of 'le petit sens et discrecion' of Chambo. ${ }^{138}$ In another case that described an even more violent madness, the merchant Gile le Treulier fell into 'folie et debilitacion de son sens' because of losses and damages he had suffered. The letter also described him as 'comme furieux', all of which caused him to commit suicide in $1421 .{ }^{139} \mathrm{Folie}$, then, could work on multiple levels of meaning, ranging from a youthful error to a serious threat to oneself or others. When it was used to describe a more serious issue, it generally appeared alongside additional terms.

The term ydiot was also a legal word, though it was not used in the customals to refer to the type of madness that might cause someone to commit a crime. Instead, as other scholars have shown for Europe more generally, it was used as a translation of the Latin term idiotus and usually referred to someone who was mad from birth. ${ }^{140}$ It appears in twelve remission letters, however, and unlike folie, it is generally used alongside multiple terms to describe a kind of violent madness rather than simply foolish behavior. For example, in the earliest use found, discussed in more detail above, Pierre de Solente was described as an 'ydiote' along with five other terms when he killed his son in $1376 .{ }^{141}$ In another case from 1391, the ironically named Jehan le Sage (who was 'given the said surname as a joke'), servant of François de L'Hospital, was 'comme idiot et lunatique'. At the instigation of a prostitute, he hit another woman and then attacked and wounded two

137 ANJJ 114 fo $142 v$ no 270: 'folly'.

138 ANJJ 140 fo 83 no 67 : 'called the fool'; 'like a complete idiot, not having sense nor discretion'; 'the little sense and discretion'.

139 AN JJ 171 fo $244 \mathrm{~V}$ no 429 : 'folly and debilitation of his sense'; 'as if furious'.

140 Turner 2013a, pp. 18-20; 28; 235-236.

141 AN JJ 110 fo 125 no 108: 'idiot'. 
sergeants who responded to the scuffle. ${ }^{142}$ While specific legal terminology was being used in remission letters, they were used far less often than other words and seldom with the kind of careful distinction between different concepts that can be seen in normative texts like law codes.

\section{Religion}

In addition to medicine and the law, religious texts also discussed mental illness. The evocative imagery of people existing outside their sense, understanding, memory, and reason stems in part from the biblical concept of the mad person, who lacks spiritual knowledge and fails to recognize God, as the opposite of the wise person. This kind of foolishness held up as the inverse of wisdom is particularly prevalent in the Old Testament and especially in the Book of Proverbs. ${ }^{143}$ In Latin, the most common term used for this type of madness is stultus, ${ }^{144}$ though perhaps the most famous reference to madness in the Psalms, Dixit insipiens, or 'the fool says in his heart there is no God', appears in two different Psalms. ${ }^{145}$ Raoul de Presles translated the Bible into French as part of Charles V's translation project. In his French translation of the psalms, he translates insipiens as le fol in Psalm 13, but as 'celui qui nestoit pas sage' ('the one who is not wise') in Psalm $58{ }^{146}$ This suggests that for Raoul de Presles, it was important to emphasize the way madness was the opposite of wisdom. Madness as perceived by the world was not always understood negatively in the Bible, however. Through the figure of inversion, the same terms used to describe the opposite of wise action could also be

142 ANJJ 140 fo 265 no 234: 'lui aeste le dit seurnom mis par derrision'; 'like an idiot and lunatic'. François de l'Hospital was the chamberlain of Charles VI's brother Louis, duc de Touraine at the time.

143 Several French translations of parts of the Bible were circulating in this period. Berger 1884. These stories also circulated in vernacular sermons. For more on sermons, see Zink 1976.

144 The Latin Biblical citations come from Weber 1969. See First Kings 25:25, Job 5:2, Psalms 48:11, Psalms 91:7, Proverbs 7:22, Proverbs 9:13, Proverbs 10:1-25, Proverbs 11:29, Proverbs 12:15, Proverbs 13:16-20, Proverbs 14:3-29, Proverbs 15:2-21, Proverbs 17:2-28, Proverbs 18:2-13, Proverbs 19:3-29, Proverbs 24:7-9 and 30, Proverbs 26:1-12, Proverbs 27:3 and 22, Proverbs 28:26, Proverbs 29:9-11 and 20, Proverbs 30:22 and 32, Ecclesiastes 2:12-19, Ecclesiastes 4:5, 13 and 17, Ecclesiastes 6:8, Ecclesiastes 7:5-11, 18 and 26, Ecclesiastes 10:1-6, 13-15, Ecclesiastes 18:18, Ecclesiastes 21:22 and 26-28, Ecclesiastes 22:9-22, Ecclesiastes 27:12, Isaias 32:4-6, Jeremias 10:14, Luke 12:20, and First Corinthians 3:18-19.

145 Insipiens gets used both in terms of folly and in terms of insanity, as these concepts are used in the Bible. See Psalm 13:1, Psalm 38:9, Psalm 52:1, Proverbs 10:18, Proverbs 14:1, Proverbs 26:8, Ecclesiastes 10:12, Ecclesiastes 20:14 and 33, and Isaias 32:5 for insipiens as the inverse of sapiens. See Psalm 48:11 and 13, Psalm 91:7, Luke 6:11, 2 Peter 2:16 for insipiens as insanity. 146 BL Lansdowne 1175. See also Bonnardot 1884, p. 41, p. 117, p. 143, p. 153, and p. 262. 
understood as the positive state of soothsayers and prophets, ${ }^{147}$ or the way Jesus was perceived by unbelievers. ${ }^{148}$ One pertinent example of this comes from the Fourth Book of Kings 9:11, when the prophet Eliseus anoints Jehu. The servants present ask, 'why came this mad man to thee', referencing Eliseus. In Latin, the term is insanus, which Raoul de Presles translates somewhat awkwardly as 'ce hors du sens', or 'this one out of his senses.' ${ }^{149}$ In Christian understanding, then, these terms had multiple and varied significations. In interpreting these Biblical cases and trying to understand their significance in more general terms, medieval theological texts treated madness as a loss of human reason, and Latin theological terms for madness taken from the Bible, such as insipiens, insania, and dementia, imply this lack..$^{150}$ The Latin biblical terminology for a more violent kind of madness uses the terms insania, furor, amentia, and dementia as well as occasionally insipiens. ${ }^{1{ }^{1}}$ Deuteronomy 28:28, for example, reads 'percutiat te Dominus amentia et caecitate ac furore mentis' ('the Lord strike thee with madness and blindness and fury of mind')..$^{152}$ Despite the availability of French terms such as fureur or enragie to describe this type of madness, Raoul de Presles again chose to translate this concept as 'hors du sens.' ${ }^{153}$ This was not because he did not have a sense of the alternative vocabulary, however. In Fourth Kings 19, he translates insanus, the same term from Fourth Kings 9, as 'forsenerie', saying that punishment comes from your 'forsenerie' against God, and that you are 'forsenez' against Him, interestingly turning to the legal terminology.

While not many of the terms used in these texts were unique to religious discourse, the term demoniacle indicated the involvement of a demon. This term appeared in remission letters only five times, usually with the caveat comme or 'as if'. In the case of Jehannecte Troppé discussed above,

147 Fourth Book of Kings 9:11 and 19:28 (insanus); Prophecy of Isaias 44:25 (furor).

148 Gospel of Mark 3:21 (furor); Gospel of John 10:20 (insanus); Acts of the Apostles 12:15 and 26:24 (insanus); First Corinthians 14:23 (insanus).

149 All English translations of the Bible come from Challoner 1971. The idea that a fool in the world could be wise in the eyes of God was picked up by a number of medieval saints, most notably St. Francis of Assisi. Saward 1980, pp. 84-89.

150 Fritz 1992, p. 7.

151 Deuteronomy 28:28 (amentia and furore mentis); Prophecy of Isaias 24:6 (insanie); Prophecy of Jeremias 25:16 (insanie); Prophecy of Zacharias 12:4 (amentia) Book of Wisdom 14:21-31 (insaniae) Gospel of Luke 6:11 (inspientia). In the French translation of the psalms, furor was translated as fureur, insensate as insensible, and fatuus as fatuite. See Bonnardot 1884, p. 41, p. 117, p. 143, p. 153 , and p. 262.

152 Deuteronomy 28:28.

153 See Tobler and Lommatzsch 1925-, vol. 3, pt. 2, p. 2360. So, for example, in Brunetto Latini's thirteenth-century Li Livres dou tresor, he notes that l'om(e), quant il met son cors en peril par ire et par furor, il n'est mie fors; mais cil qui se met en peril par droite conoissance, est fors'. 
for example, Jean de Rinel and her family used it to be inconclusive about whether her visions were caused by supernatural or natural sources. Both these possibilities were equally reasonable according to different strands in intellectual thought. In addition to Jehannecte Troppé's case, it is used in a 1381 letter on behalf of Denisot Bornigon, who claimed to have been falsely accused by a man who had been 'hors du sens et demoniacle' for two years and had even been taken to a saint's shrine to seek treatment. ${ }^{154}$ Another case from 1393 involves a man who slandered the King of France, Charles VI, but who is described as 'frenetique et demoniacle' in addition to being drunk at the time of his treasonous statement. ${ }^{155}$ In a letter from 1488 , the term was used to describe a woman whose madness had been caused by a sorcerer. ${ }^{156}$ Finally, in a case with close parallels to Jehannecte Troppé's, in 1492 Charlotte Caignaude explained that her second husband, Anthonie Fornier, drank too much and abused her so much that she would have died if the neighbors had not intervened. When she moved out of their home and went to stay with her family, Anthonie threw her belongings into the street like 'ung foul et demoniacle. ${ }^{157}$ In every case, the term is used in conjunction with others.

Religious ideas about the mad revolved around medieval anxieties about the relationship between body and soul, and in the fourteenth century these anxieties began to focus on the question of possession. The body ungoverned by the mind was a threat to the immortal soul, but it could also be a sign of possession, either divine or demonic. Perhaps the most disquieting aspect of madness for both theologians and physicians was that it often had no evident somatic symptoms. ${ }^{158}$ As Jean-Claude Schmitt argues, 'demoniacs are masters neither of their desire nor of their gestures'. ${ }^{159}$ This troubling supernatural state mirrored a state of mental disturbance. Most manifestations of madness were only recognizable through the behavior of the individual suffering from the disease, which meant that, like possession which resembled madness, it had to be discerned from externally observable behavior. ${ }^{160}$ The instability of madness as a disease was a serious concern

154 AN JJ 120 fo 17 no 24: 'out of his senses and demonically possessed'.

155 AN JJ 144 fo 270 no 469: 'frenetic and demonically possessed'.

156 ANJJ 220 fo $6 \mathrm{v}$ no 12.

157 AN JJ 223 fo $24 \mathrm{~V}$ no 41: 'a fool and demonically possessed'.

158 Fritz 1992, pp. 133-138. While frenzy and lethargy both included fever, mania and melancholia did not. This instability, according to Fritz, made mania and (especially) melancholia the focus of medical discourse in a way that frenzy and lethargy were not.

159 Schmitt 1990, p. 127: 'les démoniaques ne sont maîtres ni de leur volonté ni de leurs gestes'. 160 Nancy Caciola has done quite a bit of work on the attempts to discern possession. Although she refers to the fact that madness was a possible interpretation of possessed behavior, she does not discuss the ramifications of this possibility in detail. Caciola 2003. 
for medieval theologians, because the question of whether the behavior perceived as mad was caused by a natural illness, demonic possession, or divine possession determined the treatment of the person involved.

In Nicole Oresme's De causis mirabilium, a work seeking natural and reasoned explanations for miraculous phenomena composed in the 1340s, before his larger project of Aristotelian translation, ${ }^{161}$ he explained madness in relative terms, noting that everyone is affected by 'vapours in the brain'. He notes that 'certain healthy people [...] speak spontaneously and sometimes say certain things to which they are not paying attention and about which they are not thinking, like excited, angry men perhaps about wars'. Similarly, he notes that 'lighthearted people sing' without thinking about what they are doing. From this, he turns to the idea that these same vapours are involved in the behavior of maniacs and melancholics, who therefore 'are not able to be silent [...], and just as species of the fantasia occur to them, they express them so, because they do not know how to control themselves or how to hold back from what should not be said. Look inside yourself: if you were saying all the things which occur to you now on this, now on that, then no matter what or how much you said, people would surely call you a fool. ${ }^{162}$ Oresme defined madness, then, as an inability to censor oneself, a lack of control between thought and speech, and as springing from natural causes, these 'vapours' that arise in the brain. ${ }^{163}$ The theory that mad people were simply saying and doing things that sane people prevented themselves from doing, not that they were saying and doing things that were completely inexplicable, creates an image of madness that is not far removed from sanity. There is indeed a method in the kind of madness Oresme imagined, even though it would be difficult for a sane person to follow the peregrinations of the

161 Bert Hansen provides an overview of Oresme's work criticizing astrology and the belief in magic. See Hansen 1985, pp. 3-16.

162 Hansen 1985, p. 252-253, III.7: 'Dico $7^{\circ}$ quod in multis hominibus fiunt multe cogitationes et elevationes fumorum et motus in cerebro et circa instrumenta potentiarum anime et etiam sensuum exteriorum. Unde quosdam sanos videmus qui per se loquuntur et quandoque aliqua loquuntur ad que non advertunt nec de quibus cogitant, sicut animosi et irati forte de bellis aut et cetera. Et lascivi cantant in laborando quandoque et faciendo alia ita quod quamvis ad cantum suum non advertant et cetera. Et in maniacis et melancolicis ascendunt fumi multi et precipue circa cerebrum et instrumenta anime et potentiarum eius, ut notum est; ideo non possunt tacere nec etiam quiescere in aliis membris et sicut occurrunt species fantasie sic exprimunt quia nesciunt se corrigere nec abstinere a non dicendis. Vide in te: si loquereris omnia que tibi occurrunt modo de uno modo de alio, que et quot tu diceres, certe homines dicerent te fatuum'. 163 To give just one example, in AN JJ 144 no 469 fo 270 , a man explains that he committed treason by calling the king mad because he himself was a 'povre homme insensible, homme frénétique et démoniacle'. 
conversation. But, he suggests, it would be no more difficult to understand a mad person's conversation than to understand the random and varied thoughts of a sane person. Rather than lacking reason, Oresme suggested that mad people were merely uncensored.

Oresme went on to address the issue of the similarities between the perceived behavior of mad people and that of people possessed by the devil, arguing that, 'As to the second question [i.e. whether maniacs are demoniacs], as I have said above, those who do not know direct, natural causes flee to demons; some flee to the heavens, others to God [as the cause]. And as such things seem marvelous, people then attribute etc., but this is wrong. ${ }^{164}$ Oresme proceeded to explain that, since Avicenna had provided medical cures for madness, madness was clearly a physiological disease, and not a supernatural one.

Although there was a clear medical understanding of the sources of visionary experiences, at the same time that Jean de Rinel was writing on Jehannecte Troppés behalf, the issue of discernment of spirits was becoming more and more important to theologians such as Jean Gerson. ${ }^{165}$ Gerson focused on the similarities between somatic madness and possession, both divine and demonic. His main concern was discerning between divine and demonic possession, ${ }^{166}$ but within this literature he also discussed the differences and similarities of possession and madness. Gerson was concerned about determining the truth of revelations, explaining in a treatise written in 1402 that, although some revelations are true, many of them come from the illness of madness, saying '[s] uch a person should think of such matters as resulting from an injury done to the imagination and should worry about being ill in the way that insane, manic, or depressive people are'. ${ }^{167}$ Much of what

164 Hansen 1985, pp. 262-263: 'Ad aliud ut superius dixi illi qui nesciunt causas immediatas et naturales fugiunt ad demones, alii ad celum, alii ad Deum. Et quia talia videntur mirabilia ideo attribuunt et cetera, sed hoc est falsum'.

${ }_{165}$ Indeed, as Hansen points out, Gerson was influenced by Nicole Oresme's work in his own consideration of miracles and magic. In contrast to Oresme, Gerson allowed a much larger space for demons, but he also acknowledged the possibility of natural explanations. Hansen 1985 , pp. 114-119.

166 Both Caciola 2003 and Newman 1998 provide excellent, but very different, examinations of efforts to discern between divine and demonic possession. However, although both note that the behaviors exhibited by the possessed were similar to those exhibited by the mad, both authors focus more on what that means for the concept of possession, treating madness as a known entity.

${ }_{167}$ Translation comes from Gerson 1998, p. 339. 'Et si quae talia praeter solitum evenire circa eum contigerit, rejiciat a se cum sancto, humili verecundoque pudore. Deputet talia vel laesioni 
worried theologians about madness involved the popular belief that mad people had prophetic powers.

Gerson also sought to limit the excessive fasting that many female mystics were practicing. ${ }^{168}$ Although he often mentioned the possibility that actions that might appear holy could be inspired by the devil, he also noted the likelihood that they were signs of mental disturbance. The linkage Gerson perceived between madness and fasting was actually cyclical. He explained that

excessive abstinence and drunken overeating both lead to a similar end, except that excessive abstinence is harder to remedy, for it brings incurable illness from brain damage and mental disorder. It happens then through mania or rage or other melancholy passions that phantasms become so deeply rooted and buried in the brain that they are thought to be true objects that appear outside the mind [...] Medical books are full of such monstrous apparitions and disturbances in the power of judgment resulting from injury to the interior powers. Concerning such people, Jerome says that they are more in need of the remedies of Hippocrates than the counsel of others. ${ }^{169}$

The dangers of excessive fasting, according to Gerson, are physiological. By starving oneself, one can actually cause mania, rage, or melancholy to such an extent that visions occur. Gerson was willing to pass such worrisome cases on to physicians, arguing that confessors (such as himself) were not equipped to provide remedies for the physiologically insane.

propriae phantasiae, et se habere aliquid simile phreneticis, et maniacis aut melancholicis reformidet'. Gerson 1962, vol. 3, p. 40.

168 The seminal work on this topic is of course Bynum 1987. However, it is important to note the contribution to this concept by Caciola 2003. Caciola argues that Bynum and others have overemphasized the hagiographical views of the confessors who wrote these women's lives. She contends that any examination of these women's actions has to take into account the fact that they were seldom sanctioned by the church, and that the larger population viewed them with serious suspicion.

169 Gerson 1998, pp. 345-346. 'Itaque ad par exitium vergunt abstinentia nimia et crapulosa voracitas; nisi quod irremediabilior est excessus in abstinentia; quia morbos affert incurabiles ex laesione cerebri et rationis perturbatione, quo fit ut per maniam aut furiam vel caeteras passiones melancolicas sic profundantur et intime radicantur phantasmata interius reservata in cerebro, quod esse reputantur verae res extrinsecus apparentes, et audire se putat homo, videre vel tangere quod nullo modo sensu exteriori percipitur. [...] Pleni sunt medicorum libri de portentuosis hujusmodi apparitionibus et judicorum corruptionibus ex laesione virium interiorum nascentibus. De his ait Hieronymus quod magis indigent fomento Hypocratis quam aliorum consilio'. Gerson 1962, vol. 3, p. 44. 
Gerson imagined the devil as the instigator of possessed behavior, but in the fifteenth century more and more focus was placed on sorcerers as the devil's assistant. The idea that witchcraft could be used to make other people mad was current in court circles in the late fourteenth and early fifteenth centuries, when the French nobility was seeking an explanation for Charles VI's madness. ${ }^{170}$ Indeed, when Jean sans Peur, duke of Burgundy, arranged for the murder of Louis, duke of Orléans and brother of the king, he justified the act by accusing Louis of causing Charles VI's madness with the aid of sorcerers. ${ }^{171}$ Many scholars have addressed the burgeoning interest in sorcery in the mid-fifteenth century, suggesting that popular belief and elite concern were coming together at this time. ${ }^{172}$ The belief that sorcery could cause illness and particularly madness was developed further in fifteenth-century treatises by Johannes Nider and Heinrich Institoris. ${ }^{173}$ It is possible that the supplicants seeking remission were aware of these shifting attitudes in religious and intellectual circles from sermons, and certainly the royal notaries would have been familiar with the treatises and their impact on legal discourse.

Bewitchment by a sorcerer was mentioned as a source of madness increasingly from the middle of the fifteenth century. ${ }^{174}$ The earliest reference to sorcery in a letter about madness appeared in 1404, when a man suffering from the falling sickness (caduc) that caused him to become 'furieux et fol' chased a woman and beat her to death with a rock, screaming, 'old whore, you have bewitched [encaraté] me'. ${ }^{175}$ However, it was not until the 1450 s that sorcerers appeared in the remission letters as directly causing madness. ${ }^{176}$ These later letters blamed sorcerers for having caused mad or possessed behavior and were generally not written on behalf of the mad person, who usually had not committed any crime, but rather for the mad person's family and neighbors who had sought out a renowned sorcerer and killed him or her

170 Bellaguet 1842 , vol. 2, pp. 24-25.

171 Coville 1932 published an excerpt from Jean Petit's Justification on pages 314-315. See also Veenstra 1998, pp. $3^{6-67}$ for a discussion of Petit's work in the context of the Dukes of Burgundy and their interest in sorcery.

172 See the articles in Jolly, Raudvere, and Peters 2002; Paravy 1979; and of course the seminal studies from the 1970s, Russell 1972 and Cohn 1975.

173 Institoris and Sprenger 2006; Nider 1999. These texts and the killing of witches are discussed in more detail in Pfau 2013a.

174 For more on this topic, see my essay, Pfau 2013a, pp. 50-71. This fits the chronology of witchcraft literature. See especially Cohn 1975; Jolly, Raudvere, and Peters 2002; Russell 1972.

175 AN JJ 158 fo 168 no 36o, edited in Guérin 1909, vol. 8, pp. 38-41: 'furious and mad'; 'Pute veille, tu m'as encaraté'.

176 See AN JJ 181 fo 67 V no 123 (in 1452); AN JJ 182 fo $5^{1}$ no 85 (in 1453); AN JJ 182 fo 53 no 88 (in 1453); and AN JJ 182 fo $53 \mathrm{v}$ no 90 (in 1453) for the earliest cases I found. 
in an attempt to break the spell. Sorcery led one girl in 1457 to 'run crazily [folle] around the fields completely naked ${ }^{\prime 17}$ and a man in 1480 to become 'hors du sens et memoire' and impotent. ${ }^{17}$ The language used to describe madness caused by a sorcerer did not differ in any way from the language used to describe madness that developed from other causes.

The religious, literary, and political spheres in which the notaries interacted with each other and with other intellectuals may not have had a direct impact on their work in the royal chancery, but they were able to bring to bear their own knowledge of the significance of madness and possession in the political arena. There were times when determining whether a person suffered from a natural illness or a supernatural possession was absolutely central to the work undertaken, but there were also times when vocabulary could be flexible, and such considerations were insignificant.

In their attempts to find a conceptual vocabulary about madness, the composers of remission letters had a number of different cultural resources from which to draw. The language used to describe madness in remission letters varied widely, using multiple discourses in many different constellations and creating a fluid vision of the nature of madness. Most of the supplicants for remission described themselves as poor manual laborers and were most likely illiterate. The royal notaries, in contrast, were not only literate, but active in literary circles and a few were members of the French humanist movement. ${ }^{179}$ It was thus in the interstices of discourse that the remission letters were composed. The language used is often vague and repetitious, but these iterations signal different contexts for understanding madness.

The notaries and supplicants who composed remission letters engaged in the process of constructing their concepts of madness through language. ${ }^{180}$ The fluidity of possible terminology and definitions allowed for different levels of madness to emerge within and between remission letters. This spectrum of madness ranged from foolishness or stupidity all the way to insanity or murderous rage. Remission letters used a number of terms to

177 AN JJ 187 fo 89v no 173: 'courroit folle parmy les champs toute nue'.

178 AN JJ 208 fo 11 no 20 : 'out of his senses and memory'.

179 Famiglietti 2004, p. 34.

180 There has been an increasing interest in the ways notaries in this period were shaping how people defined things, through the writing of wills, contracts, and other legal documents like remission letters. As Daniel Smail notes, 'by the mid-fourteenth century few people, certainly few propertied people, went through life without encountering the notaries in some official capacity on one or more occasions. [...] Despite this contact, notaries are not credited, as are the clergy, with a role in the shaping of western European culture and society'. Smail 2000, p. 23. 
discuss madness. Because madness is a contested state that is so often defined in oppositional terms, it opens up discursive possibilities by forcing writers to consider the human capacity for reason, the danger of the melancholic temperament, or the mental and physical capabilities necessary to interact with others in acceptable ways.

In seeking a vocabulary to describe Jehannecte Troppés troubling behavior, Jean de Rinel and the Troppé family were able to draw not only from the language of insanity that would have been familiar to Jehannecte's neighbors. Jean de Rinel, as part of a larger network of notaries who were active consumers of the French translations of Latin works, was able to use French terms that accessed a learned tradition. Though he and his fellow notaries may have been constrained by the legal framework of these remission letters, they were still influenced by their learned communities in the terms they chose to deploy and the kinds of knowledge those terms allowed them to claim. The next chapter focuses on the stories they chose to tell, and particularly the disruptions caused by people identified as mad. 